\title{
Perinatal Hypoxic-Ischemic Damage: Review of the Current Treatment Possibilities
}

\section{Ari FRAJEWICKI ${ }^{1}$, Zdeněk LAŠTƯVKA ${ }^{1}$, Veronika BORBÉLYOVÁ ${ }^{2}$, Sami KHAN ${ }^{1}$, Kateřina JANDOVÁ ${ }^{1}$, Kateřina JANIŠOVÄ ${ }^{1}$, Jakub OTÁHAL ${ }^{3}$, Jaromír MYSLIVEČEK ${ }^{1}$, Vladimír RILJAK ${ }^{1}$}

${ }^{1}$ Institute of Physiology, First Faculty of Medicine, Charles University, Prague, Czech Republic, ${ }^{2}$ Institute of Molecular Biomedicine, Faculty of Medicine, Comenius University, Bratislava, Slovak Republic, ${ }^{3}$ Institute of Physiology of the Czech Academy of Sciences, Prague, Czech Republic

Received March 30, 2020

Accepted October 6, 2020

\section{Summary}

Neonatal hypoxic-ischemic encephalopathy is a disorder with heterogeneous manifestation due to asphyxia during perinatal period. It affects approximately 3-12 children per 1000 live births and cause death of 1 million neonates worldwide per year. Besides, motor disabilities, seizures, impaired muscle tone and epilepsy are few of the consequences of hypoxic-ischemic encephalopathy. Despite an extensive research effort regarding various treatment strategies, therapeutic hypothermia with intensive care unit supportive treatment remains the only approved method for neonates who have suffered from moderate to severe hypoxicischemic encephalopathy. However, these protocols are only partially effective given that many infants still suffer from severe brain damage. Thus, further research to systematically test promising neuroprotective treatments in combination with hypothermia is essential. In this review, we discussed the pathophysiology of hypoxic-ischemic encephalopathy and delved into different promising treatment modalities, such as melatonin and erythropoietin. However, preclinical studies and clinical trials are still needed to further elucidate the mechanisms of action of these modalities.

\section{Key words}

Hypoxia - Hypoxic-ischemic encephalopathy - Immature brain • Treatment

\section{Corresponding author}

V. Riljak, Institute of Physiology, First Faculty of Medicine, Charles University, Prague, Czech Republic. E-mail: vladimir.riljak@lf1.cuni.cz

\section{Introduction}

Neonatal hypoxic-ischemic encephalopathy (HIE) is a form of neonatal encephalopathy (NE) caused by a hypoxic-ischemic (HI) insult during the perinatal period (Dammann et al. 2011, Volpe 2012). NE is a neurological syndrome that can occur due to an intracranial hemorrhage, hypoglycemic event or prolonged hyperbilirubinemia; however, an HI insult is the most frequent cause. Perinatal HI injury is caused by oxygen deprivation in the developing neuronal tissue. Motor disabilities, seizures, impaired muscle tone and epilepsy are few of the main signs observed in the first few days of life (Leviton and Nelson 1992). Currently, many NEs are classified as HIE despite a lack of evidence of a HI insult (Volpe 2012). One of the most useful systems for neonatal HIE classification is the Sarnat grading scale staging based on clinical presentations of infants (alertness, seizures, muscle tone, etc.) (Sarnat and Sarnat 1976, Wachtel and HendricksMuñoz 2011).

Neonatal HIE affects approximately 3-5 children per 1000 live births in high-income countries and 12 neonates per 1000 live birth in low- and mid-income countries. The prevalence stay the same, in spite of improving the health care (Lawn et al. 2005, Lee et al. 2013, Wood et al. 2016). Neonatal HIE is also responsible for one-fifth of neonatal deaths worldwide (1 million death per year) (Lawn et al. 2005, Millar et al. 
2017). Studies have shown that $20 \%$ of all neonates with HIE will die in the new-born period, and $25 \%$ from those who survive will suffer from a permanent neurologic deficit. Up to $40 \%$ of neonates suffering from perinatal asphyxia will have moderate NE. Such neonatal HIE may cause a large spectrum of impairments in motor and cognitive functions, whereas severe encephalopathy often leads to death (Robertson et al. 1989, Pin et al. 2009, Wachtel and Hendricks-Muñoz 2011). Additionally, male neonates compared to female neonates animals tend more to develop neurological and motoric impairment (Murden et al. 2019, Riljak et al. 2020).

Despite an extensive research effort regarding various treatment strategies to prevent the abovementioned consequences, therapeutic hypothermia with neonatal intensive care unit (NICU) supportive treatment (respiratory management, circulatory management, fluid and electrolyte management, renal management, hematological management and follow-up of perfusion with maintained brain perfusion pressure) is the only approved method and serves as the gold standard for neonates who have suffered from moderate to severe HIE (Choi et al. 2012, Ergenekon 2016, Alsina et al. 2017). Unfortunately, this method is only partially effective in severe HI events (Choi et al. 2012, Jacobs et al. 2013, Davidson et al. 2015, Millar et al. 2017). Despite the proven effectiveness of hypothermic treatment, which involves cooling of the newborn head or even whole body, it fails to completely prevent neurological deficits (Edwards et al. 2010, Tagin et al. 2012, Wassink et al. 2019). Therefore, new treatment strategies are being investigated continuously to improve either the effect of hypothermia treatment (HT) on HIE or to identify a new and more effective treatment approach (Table 1). The aim of this article is to review preclinical and clinical studies on treatment for neonatal HIE, the available studies will be divided according to treatment strategies into categories A) Current treatment methods B) Experimental studies and finally C) Clinical studies.

Table 1. Summary of potential treatment methods and effects for neonatal HIE.

\begin{tabular}{|c|c|c|c|c|c|c|c|}
\hline Treatment & \begin{tabular}{|c|} 
Inhibit \\
Excitotoxicity \\
\end{tabular} & $\begin{array}{c}\text { Prevent } \\
\text { Oxidative stress }\end{array}$ & $\begin{array}{l}\text { Prevent BBB } \\
\text { disruption }\end{array}$ & $\begin{array}{l}\text { Prevent cell death } \\
\text { (necrosis/apoptosis) }\end{array}$ & $\begin{array}{c}\text { Anti- } \\
\text { inflammation }\end{array}$ & Angiogenesis & Neurogenesis \\
\hline$N A C$ & & $\sqrt{ }$ & & & $\sqrt{ }$ & & \\
\hline Deferoxamine & & $\sqrt{ }$ & & $\sqrt{ }$ & & & \\
\hline Edaravone & & $\sqrt{ }$ & & $\sqrt{ }$ & & & \\
\hline Resveratrol & & $\sqrt{ }$ & & $\sqrt{ }$ & $\sqrt{ }$ & & \\
\hline$D H A$ & $\sqrt{ }$ & & & $\sqrt{ }$ & $\sqrt{ }$ & & \\
\hline$A D N F-9$ and $N A P$ & $\sqrt{ }$ & $\sqrt{ }$ & & & & & \\
\hline Osteopontin & & & & $\sqrt{ }$ & $\sqrt{ }$ & & $\sqrt{ }$ \\
\hline Interferon $\beta$ & & & & & $\sqrt{ }$ & & $\sqrt{ }$ \\
\hline Sodium butyrate & & & & $\sqrt{ }$ & $\sqrt{ }$ & & $\sqrt{ }$ \\
\hline Azithromycin & & & $\sqrt{ }$ & & $\sqrt{ }$ & & \\
\hline Methylprednisolone & & $\sqrt{ }$ & & $\sqrt{ }$ & $\sqrt{ }$ & & \\
\hline Leptin & & & & $\sqrt{ }$ & $\sqrt{ }$ & $\sqrt{ }$ & $\sqrt{ }$ \\
\hline Cannabinoid agonist & $\sqrt{ }$ & $\sqrt{ }$ & & $\sqrt{ }$ & 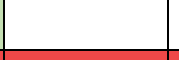 & & $\sqrt{ }$ \\
\hline Erythropoietin & $\sqrt{ }$ & $\sqrt{ }$ & & $\sqrt{ }$ & $\sqrt{ }$ & $\sqrt{ }$ & $\sqrt{ }$ \\
\hline Melatonin & $\sqrt{ }$ & $\sqrt{ }$ & & $\sqrt{ }$ & $\sqrt{ }$ & & \\
\hline Allopurinol & & $\sqrt{ }$ & & & & & \\
\hline Xenon & $\sqrt{ }$ & & & & & & \\
\hline Argon & $\sqrt{ }$ & & & & & & \\
\hline $\mathrm{MgSO}_{4}$ & $\sqrt{ }$ & $\sqrt{ }$ & & & $\sqrt{ }$ & & \\
\hline Topiramate & $\sqrt{ }$ & & & $\sqrt{ }$ & & & \\
\hline Monosialoganglioside & $\sqrt{ }$ & & & $\sqrt{ }$ & & & $\sqrt{ }$ \\
\hline Stem cell & & & & $\sqrt{ }$ & $\sqrt{ }$ & $\sqrt{ }$ & $\sqrt{ }$ \\
\hline
\end{tabular}

NAC - N-Acetyl-L-cysteine, $\mathrm{MgSO}_{4}$ - magnesium sulphate, ADNF-9 and NAP - activity-dependent neurotrophic factor 9 (ADNF-9) and novel ADNF-9 like active peptide (NAP), DHA - docosahexaenoic acid. 


\section{Etiology and pathophysiology of HIE}

There are many causes of HIE, any of which can occur before, during or after birth (Millar et al. 2017). In the antepartum period, an $\mathrm{HI}$ insult may be due to umbilical cord accidents (e.g. nuchal cord, umbilical cord compression), excessive placental bleeding or hypertensive disorders in pregnancy. Intrapartum insult may arise from severe prematurity, fetal growth restriction, maternal diabetes, an abnormal fetal position or maternal infection. Finally, a HI insult may arise in the postpartum period as a result of brain/skull trauma, severe prematurity or critical congenital heart defects (e.g. Tetralogy of Fallot, transposition of the great arteries) (Volpe 2001, Martinez-Biarge et al. 2013, Millar et al. 2017, Murden et al. 2019).

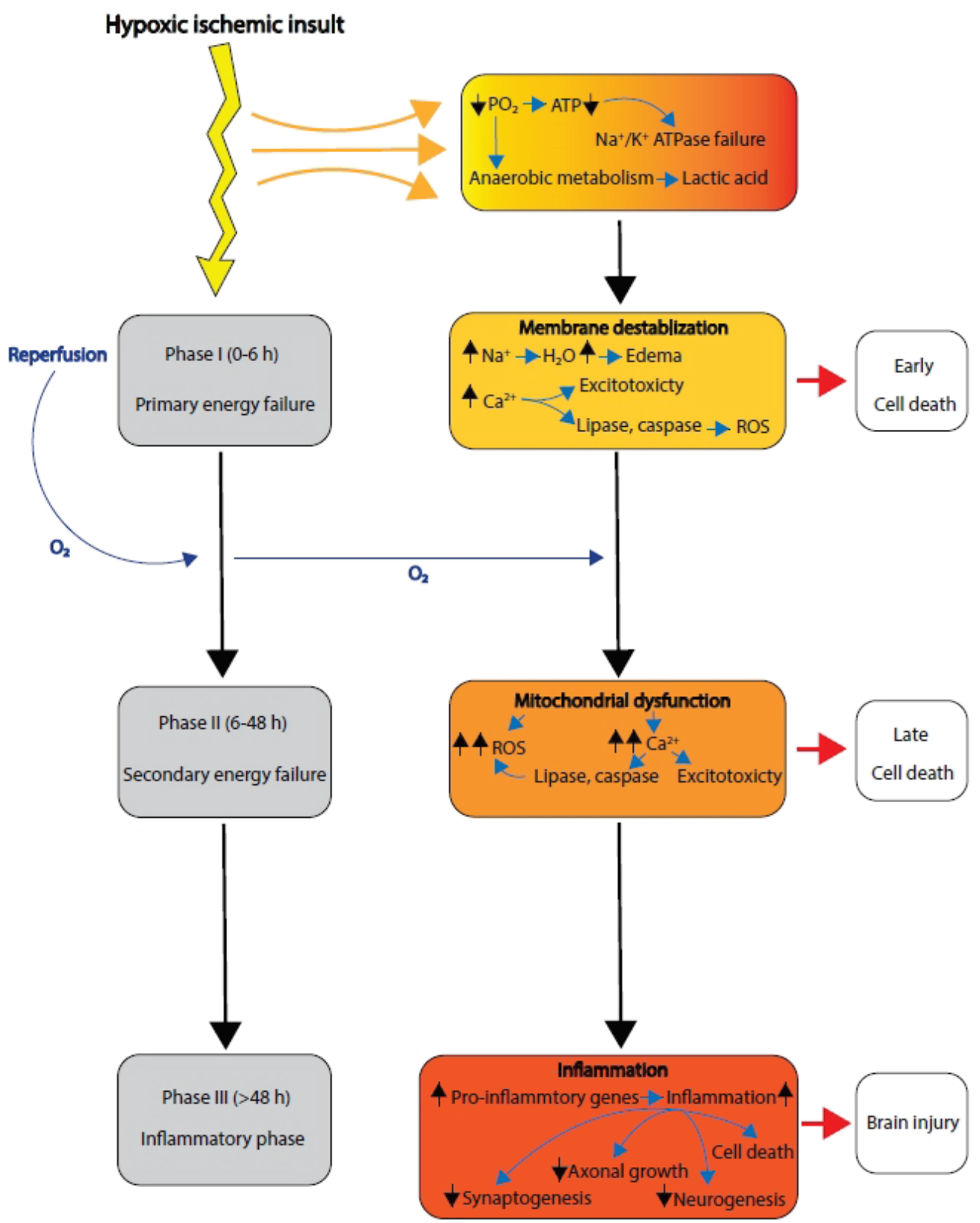

Fig. 1. Pathophysiology of $\mathrm{HIE}$ - schematic representation of HIE phases. ROS - Reactive oxygen species; $\mathrm{Ca}^{2+}-\mathrm{Calcium}^{2}$ $\mathrm{Na}^{+}$- Sodium; $\mathrm{K}^{+}$- Potassium; $\mathrm{H}_{2} \mathrm{O}$ - Water; $\mathrm{O}_{2}$ - Oxygen; $\mathrm{PO}_{2}$ - Partial pressure of oxygen.

The cellular pathophysiology of neonatal HIE consists of the following phases: primary cell energetic homeostasis failure, reoxygenation, and the 'inflammatory' phase (Arteaga et al. 2017) (Fig. 1). During an HI insult, there is a decrease in the partial pressure of oxygen, a terminal acceptor of the electron in the respiratory 
transport chain. A subsequent reduction in oxidation/ phosphorylation leads to rapid depletion of ATP within the cells. Therefore, cells modify and adapt their metabolism towards anaerobic pathways, reducing ATP production and inducing the accumulation of lactic acid (Arteaga et al. 2017). A lack of ATP causes failure of $\mathrm{Na}^{+} / \mathrm{K}^{+}$ATPase, resulting in destabilization of plasma membrane ion distribution. Intracellular accumulation of sodium ions is ensued by the movement of water into the cell. Calcium ion elevation can also activate various intracellular enzymes, such as lipase and caspase, leading to the formation of reactive oxygen and nitrogen species (ROS and RNS), which harm the mitochondria. The major outcome of these processes is cellular oedema with potential cell death. The next source of cellular energy metabolism failure is associated with reoxygenation and reperfusion processes occurring approximately $6-48 \mathrm{~h}$ after the $\mathrm{HI}$ insult (Dixon et al. 2015). When oxygen homeostasis is partially recovered, oxidative metabolism produces new reactive oxygen species. The influx of calcium into the cell and subsequent mitochondrial dysfunction are exacerbated (Arteaga et al. 2017).

Apart from mitochondrial dysfunction, an increase in expression of pro-inflammatory genes leading to acute inflammation can be observed. This phase occurs $48 \mathrm{~h}$ after the $\mathrm{HI}$ insult and can protract for months (Arteaga et al. 2017). The inflammatory phase produces chronic inflammation that impairs axonal growth and interferes with the processes of physiological synaptogenesis and neurogenesis. These events together with the previous phases eventually lead to harmful brain injury (Dixon et al. 2015, Arteaga et al. 2017). Although several theories have been proposed to be directly responsible for the cell death in perinatal brain, the exact pathologic mechanisms of HIE with subsequent neurodegeneration are not clearly understood. Currently, the treatment aims to impede neuronal destruction after $\mathrm{HI}$ insult that is achieved by hypothermia. Hypothermia represents a gold standard in treatment of HIE, however, it is far from ideal. As our understanding of pathophysiology of HIE improves, new treatment strategies should be implemented.

\section{Treatment methods}

\section{Current treatment methods}

Therapeutic hypothermia

Therapeutic hypothermia is well established as a standard treatment for neonates suffering from moderate to severe HIE. It is defined as intentional reduction of core temperature of a human patient below $36^{\circ} \mathrm{C}$ (So 2010). Current hypothermia protocols suggest starting treatment within the first $6 \mathrm{~h}$ of life with systemic cooling to either $33.5 \pm 0.5{ }^{\circ} \mathrm{C}$ for whole-body cooling or $34.5 \pm 0.5{ }^{\circ} \mathrm{C}$ for head cooling and continuous treatment for 48-72 h. Metaanalysis results suggest that both approaches exhibit similar effects (Tagin et al. 2012, Wassink et al. 2019). Nevertheless, it is easier to control whole body temperature than perform selective head cooling (Tagin et al. 2012, Wassink et al. 2019). Clinical evidence suggests that mild induced hypothermia significantly improves survival and neurocognitive outcome and decreases the risk of developing cerebral palsy in full-term infants with moderate to severe HIE (Shankaran et al. 2005, Jacobs et al. 2011, Tagin et al. 2012, Laptook et al. 2017). Unfortunately, this method is only partially effective; many infants still suffer from severe brain damage, cerebral palsy and neurocognitive disorders even when treated with hypothermia (Cotten and Shankaran 2010, Shah 2010, Douglas-Escobar and Weiss 2015, Riljak et al. 2016). Therefore, new approaches for further reduction of the harmful effect of HI injury are still needed. Many promising methods and agents have been thoroughly researched and are continuously being investigated. A few of these treatment strategies are summarized below (Fig. 2).

\section{Experimental studies}

\section{Antioxidant agents}

$N$-Acetyl-L-cysteine

N-Acetyl-L-cysteine (NAC) is an antioxidant crossing the BBB, a precursor of glutathione and an ROS scavenger. NAC reduce apoptotic cell death inhibits nitric oxide (NO) production and decreases the formation of inflammation-related cytokines (e.g. TNF $\alpha$ and IL-1 $\beta$ ) (Khan et al. 2004, Jayalakshmi et al. 2005, Parikh and Juul 2018). One of the major mechanisms of NAC neuroprotective potential is the increase in synthesis of erythropoietin (EPO) and glucose transporter type 3 via HIF-1 $\alpha$ expression (Khan et al. 2004). In combination with HT, NAC exhibited better outcomes in many aspects, such as reduced brain infarction volume and increased locomotor activity in neonatal rats exposed to hypoxia (Jatana et al. 2006). Interestingly, the effect of NAC and NAC in combination with HT seems to be at least partially sex specific (long-term neuromotor outcomes) (Nie et al. 2016). More experimental studies must be done and find the appropriate dose, timing and method of administration before clinical use (Parikh and Juul 2018). 


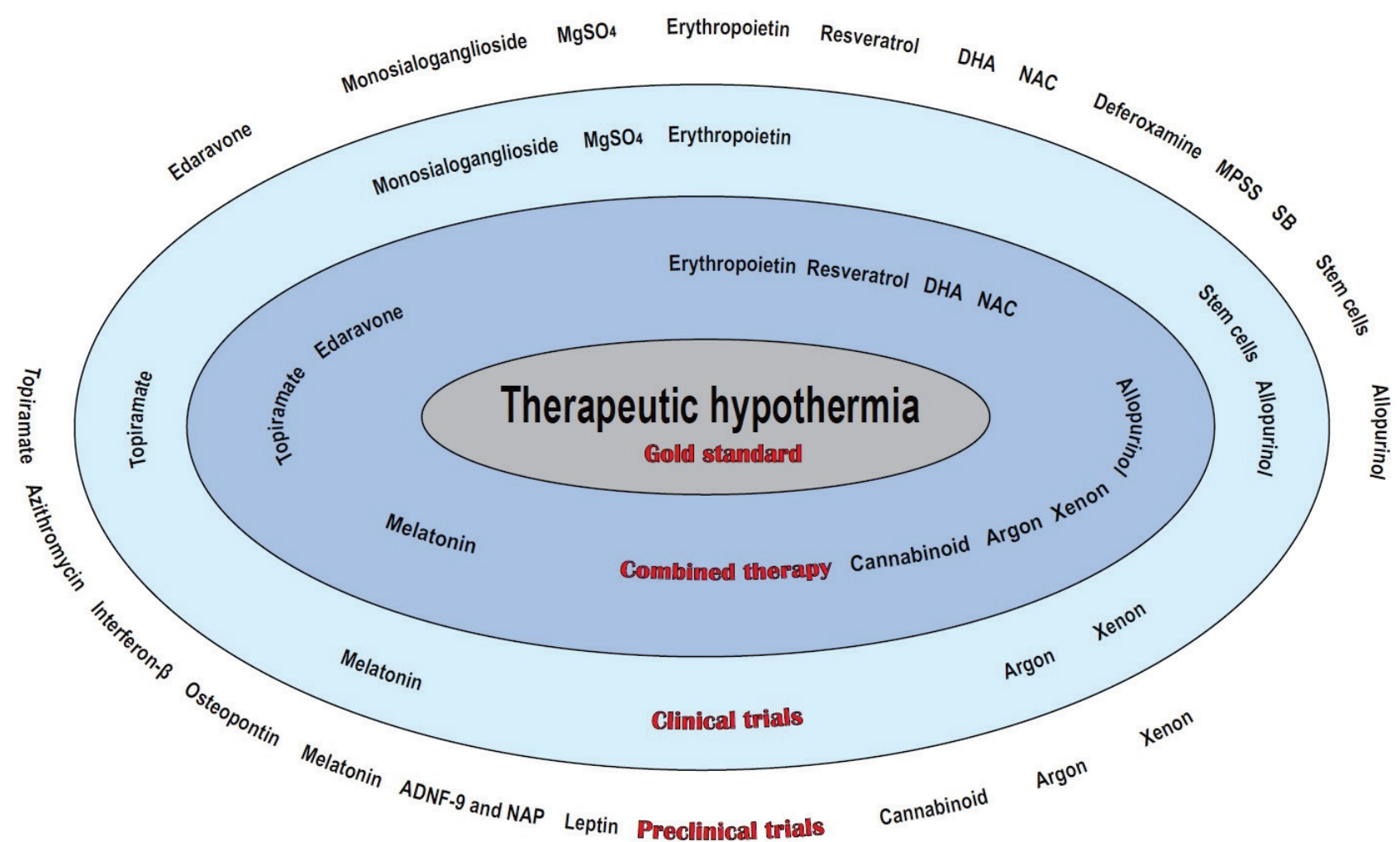

Fig. 2. Summary of the experimental and clinical studies of treatment for neonatal HIE. SB - Sodium butyrate; MPSS - Methylprednisolone; DHA - Docosahexaenoic acid; NAc - N-Acetyl-I-cysteine; ADNF-9 and NAP - Activity-dependent neurotrophic factor-9 and novel ADNF-9 like active peptide.

\section{Deferoxamine}

Deferoxamine (DF) is an iron chelator that crosses the BBB. This molecule can prevent formation of hydroxyl radicals from hydrogen peroxide with iron via the Fenton reaction (Palmer et al. 1994, Kletkiewicz et al. 2016). DF administered intraperitoneally to rats leads to increased HIF-1 $\alpha$ and EPO expression. Li et al. (2008) found that DF decreases neuronal death. These researchers suggested two mechanisms of its neuroprotective effects. The first mechanism is the abovementioned HIF1- $\alpha$ pathway, and the second mechanism is improved cell survival ( $\mathrm{Li}$ et al. 2008). DF prevents the depletion of energetic reserves of the brain tissue (Peeters-Scholte et al. 2003). It also decreases the volume of the lesion in the brain cortex and improves forelimb muscle strength; however, DF fails to improve other motor functions (Jones et al. 2008). Interestingly, intranasal DF administration is also effective if used as a pre-treatment or post-treatment of the HIE event (Hanson et al. 2009). Kletkiewicz et al. (2016) suggest that DF reduce oxidative stress not only iron chelator, but it might prevent the decrease activity of antioxidant enzyme (Kletkiewicz et al. 2016). More experimental studies must be done and find the appropriate dose, timing and method of administration before clinical use (Kletkiewicz et al. 2020).

\section{Edaravone}

Edaravone (3-methyl-1-phenyl-2-pyrazolin-5one, MCI-186) is a free radical scavenger that reacts with hydroxyl and peroxyl radicals to form stable oxidative molecules (Yamamoto et al. 1996). Furthermore, edaravone also inhibits neuronal apoptosis (Yasuoka et al. 2004), lipid peroxidation (Noor et al. 2007), and NO synthesis (Satoh et al. 2002); prevents oxidative injury (Tanaka 2002) and protects from DNA peroxidation (Takizawa et al. 2009). Yasuoka et al. (2004) found that edaravone significantly reduced neuronal cell death, apoptosis and necrosis when administered intraperitoneally $(3.5 \mathrm{mg} / \mathrm{kg}$ before insult) to neonatal rats and following $\mathrm{HI}$ insult $(3 \mathrm{mg} / \mathrm{kg}$ every $12 \mathrm{~h}$ until sacrifice). The highest effect was observed after $48 \mathrm{~h}$ of repeated edaravone doses (Yasuoka et al. 2004). Rat models showed that a combination of HT and edaravone therapy following $\mathrm{HI}$ insult leads to a significantly better neurological outcome in neonates with perinatal asphyxia. A significant decrease in rat neuronal cell death was observed when treated at $32{ }^{\circ} \mathrm{C}$ 
(32-39 $\left.{ }^{\circ} \mathrm{C}\right)$ in combination with $50 \mu \mathrm{M}(0-50 \mu \mathrm{M})$ of edaravone (Shibuta et al. 2010). However, when piglet treated with edaravone combine with HT, no additive effect was found (Yamato et al. 2020). Other studies also showed the ability of edaravone to improve memory and learning function if administered $24 \mathrm{~h}$ after an $\mathrm{HI}$ event at $9 \mathrm{mg} / \mathrm{kg}$ daily for 2, 5 or 10 days. More than 5 days of administration did not result in improvement (Noor et al. 2005, Li et al. 2018). To date, no clinical studies done with edaravone on neonates with HIE.

\section{Resveratrol}

Resveratrol is a polyphenol produced by several plants (e.g. grapevines, caper bush, and pomegranates) exhibiting antioxidative, anti-apoptotic and antiinflammatory properties (Bastianetto et al. 2015). Neuroprotective mechanisms of resveratrol include diminution of oxidative stress (ROS and RNS generation by inhibiting xanthine oxidase, and reduced glutathione formation) (Farkhondeh et al. 2020). Resveratrol might improve mitochondrial respiratory activity and can inhibit the process of apoptosis (West et al. 2007, Yousuf et al. 2009, Farkhondeh et al. 2020). Resveratrol in combination with HT reduces oxidative stress after HI (TOADER et al. 2013), but more studies are needed to investigate the timing of administration and optimal dose (Arteaga et al. 2017). Administration of resveratrol before HI insult has neuroprotective effects (volume of infarction and behaviour outcome) (Arteaga et al. 2017, Gao et al. 2018); however, its administration following an HI event fails to demonstrate clear neuroprotection (West et al. 2007, Arteaga et al. 2015). To date, no clinical trials had been done with Resveratrol on neonatal with HIE.

\section{Docosahexaenoic acid}

Docosahexaenoic acid (DHA) is a polyunsaturated fatty acid with double bonds located in third carbon from the end (omega-3 fatty acid). Mammals are not able to synthesize omega-3 fatty acids; therefore, mammals get it by consuming marine animals and plants (Arteaga et al. 2017). DHA showed a neuroprotective effect by decreasing free radicals, amyloid and lipid peroxidation, preventing neuronal cell death and inflammation in neurodegenerative and neurological disorders (Dyall 2015, Huun 2019). However, the neuroprotective mechanisms of DHA are not completely understood (Huun 2019). In a rat model, Berman et al. (2013) demonstrated that hypothermia combined with DHA
$(2.5 \mathrm{mg} / \mathrm{kg}$ ) following an HI event significantly improved neurological function and decreased brain injury compared to HT alone. DHA treatment alone did not show any significant positive outcome (Berman et al. 2013). On the other hand, a maternal diet rich in DHA during pregnancy and lactation has a neuroprotective effect on pups (Suganuma et al. 2010, Zhang et al. 2010). No clinical studies have been done with DHA as a treatment for neonatal HIE.

\section{ADNF-9 and NAP}

Recent studies demonstrated that short peptides derived from activity-dependent neurotrophic factor (ADNF) and activity-dependent neuroprotective protein have neuroprotective effects on immature brain. Protection against oxidative stress, dopamine toxicity, glucose depletion, and toxins, such as N-methyl-Daspartate (NMDA) and $\beta$-amyloid, was observed (Bassan et al. 1999, Glazner et al. 1999, Leker et al. 2002, SmithSwintosky et al. 2005). Kumral et al. (2006) compared the neuroprotective effect of ADNF-9 and novel ADNF9-like active peptide (NAP) as treatments for neonate rats that suffered from HI insult. Intraperitoneal administration of NAP and ADNF-9 within $2 \mathrm{~h}$ following an $\mathrm{HI}$ event resulted in neuroprotective effects, including inhibition of the production of nitric oxide (an RNS) and prevention of neuronal cell death, apoptosis or necrosis They administered $0.3 \mu \mathrm{g} / \mathrm{g}$ of body weight of NAP or ADNF-9 intraperitoneally $2 \mathrm{~h}$ after the $\mathrm{HI}$ event, and neuroprotective effects were observed (Kumral et al. 2006). Although, ADNF-9 and NAP showed neuroprotective effect, NAP is preferred lead peptide due to the ability to stimulate production of VIP, that allows interaction with glial cells and increase cell survival (Chiu et al. 2017). Greggio et al. (2011) showed that NAP has long-term neuroprotective effects (after 60 days of HI event), leading to a reduction of the infarction and improvement of the cognitive functions up to 7 weeks after HI injury (Greggio et al. 2011). The positive effect of NAP was observed only when administered within $6 \mathrm{~h}$ following $\mathrm{HI}$ insult and within the range of $1-1000 \mathrm{pg}$ intracerebrally or $0.01-10 \mathrm{ng}$ intraperitoneally (Sokolowska et al. 2011). No newer studies were published, and no clinical studies been done on new-born babies with this treatment.

\section{Anti-inflammatory agents}

Osteopontin

Osteopontin (OPN) is an acidic glycoprotein 
composed of 300 amino acids. OPN is synthesized not only by osteoblasts, preosteoclast and osteocytes but also by dendritic cells and macrophages (Butler 1989). OPN induces activation of macrophages and dendritic cells and secretion of interferon alpha and other cytokines that regulate Th17. OPN also regulates Th1-cell proliferation and migration. All of these functions increase inflammation and the healing reaction (Lund et al. 2009). Some experimental studies have shown that OPN is able to repair brain injury after neonatal HIE by promoting cerebral cell survival and proliferation and differentiation of oligodendrocytes and improve neurological outcome (Van Velthoven et al. 2011, Dixon et al. 2015, Zhou et al. 2020). Unfortunately, no neuroprotective effect with intranasal or intraperitoneal administration of OPN was observed in animal models after HI (Bonestroo et al. 2015). More studies must be done on OPN method of administration, timing of administration and dosing before try it in clinical trials (Zhou et al. 2020).

\section{Interferon beta}

Interferon beta (IFN- $\beta$ ) is a polypeptide synthesized by fibroblasts. IFN- $\beta$ reduces antigenpresenting activity of macrophages and microglial cells, prevents $\mathrm{T}$-cell proliferation and increases production of anti-inflammatory cytokines. IFN- $\beta$ also has the ability to induce neurogenesis (Markowitz 2007, Kieseier 2011). A few animal models have demonstrated the neuroprotective effect of IFN- $\beta$ following $\mathrm{HI}$ insult (Veldhuis et al. 2003, Dixon et al. 2016). A significant reduction of infarction and brain oedema was reported by Veldhuis et al. (2003) following 7-day subcutaneous administration of IFN- $\beta(500,000 \mathrm{U})$ to rats. IFN- $\beta$ also showed preservation of the $\mathrm{BBB}$, prevention of neutrophil influx and decrease in lesion volume by $70 \%$ after 1 day and by $85 \%$ after 21 days of IFN- $\beta$ administration (Veldhuis et al. 2003). Its intranasal application $(0.03,0.3$, and $1.0 \mu \mathrm{g} / \mathrm{kg}$ ) yielded similar positive cerebral outcomes (decreased infarct volume) and improved sensorimotor functions in rats (improved reflex behaviour time) (Dixon et al. 2016). No clinical studies been done on neonatal HIE treated with IFN- $\beta$.

\section{Sodium butyrate}

Sodium butyrate (SB) is a histone deacetylase inhibitor produced in the gut by bacterial fermentation of dietary fibres (Jaworska et al. 2017). SB exhibits neuroprotective effects in adult mice after brain injury.
However, the mechanisms of the neuroprotective action of SB remain unclear (Jaworska et al. 2017, Jaworska et al. 2019). Some studies suggest that SB reduces the expression of pro-inflammatory mediators and conversion of microglial cells to anti-inflammatory cells (Jaworska et al. 2017, Jaworska et al. 2019). Neuroprotective effects were also observed in rat neonates (Kumral et al. 2009, Janowska and Sypecka 2018, Jaworska et al. 2019). Furthermore, recent studies confirmed the ability of SB to induce neurogenesis (Ziemka-Nalecz et al. 2017) and reduce neuronal apoptosis (Sun et al. 2015). No clinical studies been done yet with SB treating neonatal HIE.

\section{Azithromycin}

Azithromycin is a macrolide antibiotic. Azithromycin has anti-inflammatory and antimicrobial effects (Parnham et al. 2014). Amantea et al. (2016) reported a neuroprotective effect of intraperitoneally administered azithromycin in neonatal rats following an HI event. Reduced brain infraction, oedema and neurological improvement was achieved only with a dose of $150 \mathrm{mg} / \mathrm{kg}$ of azithromycin. The positive effect is caused by preservation of BBB integrity and reduced infiltration of inflammatory immune cells (Amantea et al. 2016). Barks et al. (2019) also revealed that single dose of azithromycin $(45 \mathrm{mg} / \mathrm{kg})$ should be administered less than $4 \mathrm{~h}$ following an HI event to yield a positive effect. Furthermore, they found that 3 doses $(45 \mathrm{mg} / \mathrm{kg}$, $22.5 \mathrm{mg} / \mathrm{kg}$, and $22.5 \mathrm{mg} / \mathrm{kg}$ ) of azithromycin in 24-hour intervals are more effective than a single dose to decrease the infraction volume (Barks et al. 2019). Azithromycin has been studied only experimentally as a treatment for neonatal HIE (van Bel and Groenendaal 2020).

\section{Methylprednisolone}

Methylprednisolone (MPSS) is a glucocorticoid that is used as an immunosuppressive and antiinflammatory agent to treat several diseases, such as multiple sclerosis, systemic lupus erythematosus, acute spinal injury and others (Trevisani et al. 2013, Cooper et al. 2015, Hall 2016). MPSS inhibits lipid peroxidation (Daneyemez et al. 1999); therefore, it can prevent apoptosis and inflammation (Concepcion and Zhang 2018). Preclinical studies have shown that MPSS has a neuroprotective effect after a neonatal HI event. In a rat model, Daneyemez et al. (1999) reported a reduction in brain injury when $30 \mathrm{mg} / \mathrm{kg}$ MPSS was intraperitoneally administered along with vitamin E (100 mg/kg) (Daneyemez et al. 1999). The MPSS mechanism is not 
completely clear, but Altamentova et al. (2020) reported that the mechanism partially involves reductions in the pro-inflammatory effect and cytokine (CCL3, CCL5, IL18, TNF $\alpha$ ) levels following delayed MPSS treatment. Intravenous application of 3 doses of $30 \mathrm{mg} / \mathrm{kg}$ MPSS to rats 13 days following $\mathrm{HI}$ injury leads to a reduction of pro-inflammatory cytokines and chronic inflammatory cerebral damage, increased proliferation of glial cell populations and minimal proliferation of the neuronal cell population. Furthermore, improved motor functions were observed (Altamentova et al. 2020). More experimental studies must be done with MPSS before try it in the clinical field (Wang et al. 2019).

\section{Hormones}

Leptin

Leptin is a peptide hormone that is mainly produced by adipocytes and regulates body weight by suppressing appetite centers in the hypothalamus and stimulating energy expenditures (Schubring et al. 1997). Leptin exhibit antiapoptotic function and neurotrophic features and is also involved in angiogenesis, regulation of immune function, suppression of T-lymphocyte, bone formation and brain development (Dicou et al. 2001, Zhang et al. 2007). Intraperitoneal administration of leptin $(0.5-8 \mathrm{mg} / \mathrm{kg})$ to animals at time of reperfusion was most effective (Zhang et al. 2007, Kumral et al. 2012, Hu et al. 2019) and improve the spatial memory (Feng and Jiang 2018). No clinical trials been done with leptin on neonates with HIE.

\section{Anti-excitotoxic agents}

Cannabinoid agonists

Endogenous cannabinoids are important neuroregulatory substances that contribute to the control of motor behaviour, influencing the processes of learning and memory and interfering with pain perception and the immune response (Martínez-Orgado et al. 2003). Cannabinoids bind to the cannabinoid receptors (CB1 or CB2), which are coupled to a few transduction pathways, including G-proteins inhibiting calcium-voltage gated channels. Such pathways may reduce the release of glutamate. By this mechanism, excitotoxicity during $\mathrm{HI}$ insult might be prevented by reducing cell death (Nagayama et al. 1999). Exogenous cannabinoids as a non-psychoactive cannabinoid cannabidiol (CBD) and synthetic cannabinoid WIN55212 (WIN) are fully CB1 and $\mathrm{CB} 2$ agonist, while $\Delta^{9}$-tetrahydro-cannabinol (THC) partially CB1 agonist (Gilbert et al. 2007). They are also neuroprotective substances that bind to $\mathrm{CB} 1$ and $\mathrm{CB} 2$ receptors. CBD inhibit calcium influx, reduce glutamate and TNF- $\alpha$ release, decrease iNOS expression, induce hypothermia, promote immunomodulation, exhibit antioxidant activity and neurogenesis (Alvarez et al. 2008, Prenderville et al. 2015). While, WIN and THC a psychoactive cannabinoid substance inhibit glutamate releasing, prevent excitotoxicity, prevent cell death and inhibit NO synthesis (Martínez-Orgado et al. 2003, Gilbert et al. 2007). Besides, WIN also stimulate neurogenesis (Fernández-López et al. 2010). It was demonstrated that administration of CBD $(1-5 \mathrm{mg} / \mathrm{kg})$ intravenously or subcutaneously to new-born rodents following an $\mathrm{HI}$ event improves the functional activity of neurons and decreases neuronal cell death (Alvarez et al. 2008, Pazos et al. 2012). CBD should be administered no later than $18 \mathrm{~h}$ following the $\mathrm{HI}$ event. After this period, cannabinoids show a reduction in their neuroprotective effect (Mohammed et al. 2017). In new-born piglets, CBD $(10-30 \mathrm{mg} / \mathrm{kg})$ had an additive effect on HT treatment and reduced inflammation marker levels and neuronal cell death, but not cognitive improvement. (Schiavon et al. 2014, Lafuente et al. 2016, Garberg et al. 2017). To date, Cannabinoid agonist has not been studied on human neonates with HIE.

\section{Current clinical studies}

\section{Hormones}

Erythropoietin

Erythropoietin is an endogenous glycoprotein hormone that is vital for the stimulation of erythropoiesis. In addition to erythropoiesis, EPO serves many other functions, including regulating the immune system, acting as a vasoactive agent, interfering with the process of apoptosis and excitotoxicity, having antioxidative properties and promoting angiogenesis and neurogenesis (Dixon et al. 2015, Nair and Kumar 2018) (Fig. 3). At the beginning of the fetal period, EPO is synthesized in the liver; however, later during fetal development the location of its synthesis is shifted to the kidneys (Allen and Brandon 2011, Wu and Gonzalez 2015). EPO can also be synthesized in neuronal and glial tissue within astrocytes following a brain injury (Sugawa et al. 2002, Allen and Brandon 2011). When HIE occurs, the concentration of EPO increases in the cerebrospinal fluid (CSF) with an increase in EPO receptor densities in neuronal tissue (Bernaudin et al. 1999, Dixon et al. 2015). Under physiological conditions, EPO can be 
transported through the blood-brain-barrier (BBB); however, this transport is limited due to its relatively large size. Therefore, only $1 \%$ of circulating EPO crosses the BBB by diffusion (Brines et al. 2000, Wu and Gonzalez 2015). Administration of a low dosage of exogenous EPO (e.g. used in anemia treatment) does not increase EPO concentrations in the CSF (Juul et al. 1997), and considerably higher doses are required to register a significant increase in EPO concentrations within the CSF. On the other hand, under the conditions of HI, the BBB becomes more permeable, allowing EPO to diffuse across in larger concentrations (Dixon et al. 2015). Promising results of EPO administration alone (van der Kooij et al. 2008, Wu and Gonzalez 2015) or in combination with hypothermia treatment (Wu et al. 2012) call for further research regarding optimal dose adjustments and timing of administration. Currently, EPO is effective in newborns suffering from a mild HIE without any obvious side effects (Garg et al. 2018).

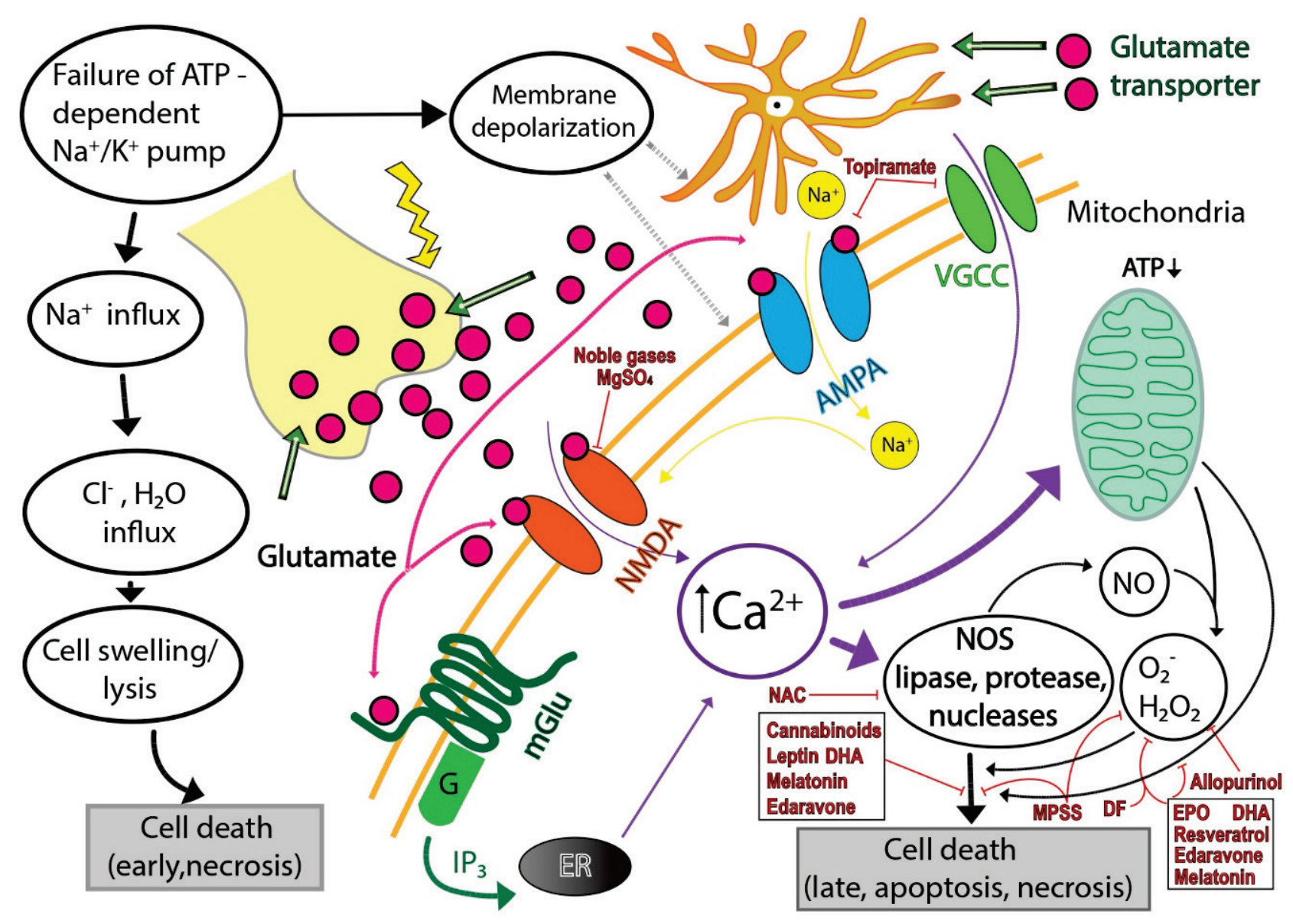

Fig. 3. Cellular changes caused by HI event and treatments to prevent it. MPSS - Methylprednisolone; DF - deferoxamine; EPO - Erythropoietin; DHA - Docosahexaenoic acid; NAc - N-Acetyl-I-cysteine; $\mathrm{MgSO}_{4}$ - Magnesium sulphate; NO - Nitric oxide; $\mathrm{O}^{2-}$ - Superoxide; $\mathrm{H}_{2} \mathrm{O}_{2}-$ Hydrogen peroxide; Nitric oxide synthase; $\mathrm{Ca}^{2+}-$ Calcium; $\mathrm{Na}^{+}-$Sodium; $\mathrm{K}^{+}-$Potassium, $\mathrm{Cl}^{-}-\mathrm{Chloride}^{2}$ $\mathrm{H}_{2} \mathrm{O}$ - Water, IP3 - Inositol triphosphate; G - G protein; ER - Endoplasmatic reticulum; NMDAR - M-methyl-D-aspartate receptor; AMPAR - a-amino-3-hydroxy-5-methyl-4-isoxazolepropionic acid receptor; VGCC - Voltage-gated calcium channels; mGluR - Metabotropic glutamate receptors.

\section{Melatonin}

Melatonin is an endogenous hormone that is secreted from the pineal gland and regulates the circadian rhythm (Baydas et al. 2005). Melatonin exhibits neuroprotective effects as an antiapoptotic agent, decrease inflammation, reduce excitotoxicity and antioxidant effect (Baydas et al. 2005, Esposito and
Cuzzocrea 2010, Maresova et al. 2010, Villapol et al. 2011). Furthermore, due to its ability to cross the BBB (Gupta et al. 2003), melatonin is widely tested in animal models. Carloni et al. (2008) studied the timing, doses and frequency of administration of melatonin treatment and evaluated the short- and long-term effects of melatonin treatment in rats. Significant reduction in 
infarction volume with improved cognitive abilities has been demonstrated following pre-treatment $(5 \mathrm{mg} / \mathrm{kg}$ or $15 \mathrm{mg} / \mathrm{kg})$ and post-treatment $(15 \mathrm{mg} / \mathrm{kg})$ with melatonin (Carloni et al. 2008). Three different studies support Carloni et al. (2008) results, but with administration of high single dose of melatonin $(100 \mathrm{mg} / \mathrm{kg})$ pre-treatment or post-treatment (Matějovská et al. 2008, Deykun et al. 2011, Mareš et al. 2012). On the other hand, Villapol et al. (2011) did not report a reduction in volume of cortical brain infarction after administration of one or two doses of $20 \mathrm{mg} / \mathrm{kg}$ melatonin intraperitoneally 1 -hour preinsult or $24 \mathrm{~h}$ post-insult. Nevertheless, a significant reduction in white matter damage was noted (Villapol et al. 2011). Moreover, Robertson et al. (2013) investigated the combination of melatonin with HT; however, the additive effect of HT was not observed (Robertson et al. 2013). Clinical studies demonstrated that a combination of melatonin $(5-10 \mathrm{mg} / \mathrm{kg}$ daily for 3-5 days) with HT (Aly et al. 2015, Colella et al. 2016) leads to significant improvement in survival without any short- and long-term neurological consequences in neonates with perinatal asphyxia (Aly et al. 2015, Jerez-Calero et al. 2020). More randomized trials must be done to validate these results (Paprocka et al. 2019).

\section{Antioxidant agents}

\section{Allopurinol}

Allopurinol is a xanthine oxidase inhibitor and free radical scavenger (Kaandorp et al. 2012). Xanthine oxidase is an enzyme that converts hypoxanthine to xanthine and xanthine to uric acid. During HI insult, an accumulation of hypoxanthine occurs. During the phase of reperfusion and reoxygenation, hypoxanthine is oxidized and produces superoxide molecule (Arteaga et al. 2017, Nair and Kumar 2018). Promising studies demonstrate a decrease in infarction volume in rats if allopurinol is administered with HT treatment (Rodríguez-Fanjul et al. 2017). However, in human neonates, clinical studies with allopurinol did not reveal any decrease in mortality nor neurodevelopmental disabilities (Benders et al. 2006, Kaandorp et al. 2012). Further human clinical studies are ongoing (Maiwald et al. 2019).

\section{Anti-excitotoxic agents}

Noble gasses

Owing to their characteristics, noble gasses, such as xenon and argon, represent great candidates for perinatal hypoxia treatment. Xenon and argon can cross the $\mathrm{BBB}$ and interact with NMDA receptors of the neuronal cell to induce anti-apoptotic signalling followed by reduced neurotransmitter release. Thus, these gasses could diminish the consequences of the process of excitotoxicity (Broad et al. 2016, Anna et al. 2020). Experimental studies suggest the decline of infarction volume in the rat cortex following xenon administration (Hobbs et al. 2008, Anna et al. 2020). However, in clinical trials with human neonates suffering from perinatal HIE, xenon in combination with HT did not lead to a significant improvement (Azzopardi et al. 2016). However, argon exhibits a positive effect when used with HT and is capable of reducing nervous tissue injury (Broad et al. 2016). An important advantage of argon administration is that it can be applied using a simple ventilator (Nair and Kumar 2018). Usage of noble gases however remains controversial (Campos-Pires et al. 2015, Azzopardi et al. 2016, Sabir et al. 2016, Amer and Oorschot 2018). Xenon in clinical studies didn't exhibit improvement neurological nor mortality (Law et al. 2018). Currently, no neonatal HIE clinical studies been done with Argon (Tolaymat et al. 2020).

\section{Magnesium sulphate}

Magnesium ion is an NMDA receptor blocker that prevents excitotoxicity (Cetinkaya et al. 2011). It stabilizes cell membranes and inhibits the formation of ROS (Hoffman et al. 1994). In addition, it may reduce inflammation reactions associated with brain injury (Sugimoto et al. 2012). Galinsky et al. (2020) reviewed the usage of magnesium sulphate $\left(\mathrm{MgSO}_{4}\right)$ in the treatment of HIE; however, their review shows inconsistent outcomes regarding its neuroprotective effect (Galinsky et al. 2020). Also clinical studies exhibit controversial results (Lingam and Robertson 2018) and more studies must be done experimentally and clinically.

\section{Topiramate}

Topiramate (TOP) is an anti-epileptic drug. It inhibits sodium and calcium voltage-gated channels and modulates $\gamma$-aminobutyric acid (GABA) receptors. It also blocks glutamate receptors, leading to inhibition of neuronal excitability. In addition, TOP is also able to increase oligodendrocyte survival, decrease neuronal apoptosis and inhibit microglial activation. These properties support the hypothesis that TOP might be a potential neuroprotective agent (Dixon et al. 2015). 
Rats and piglets receiving TOP exhibit significant decreases in white and grey matter injury following $\mathrm{HI}$ insult (Schubert et al. 2005, Noh et al. 2006), and it has a better neuroprotective effect when combined with HT (Liu et al. 2004). Clinical trials have reported that application of TOP without HT is safe, but does not have positive effects on mortality nor neurological symptoms (Filippi et al. 2018). Currently, there is one ongoing clinical trial (number of the clinical trial NCT01765218) which study the effect of TOP on new-born babies and should be complete on 2022 .

\section{Monosialoganglioside}

Monosialoganglioside is a ganglioside. Gangliosides are sphingolipids found predominantly in the neuronal membrane (Lucki and Sewer 2012). Monosialoganglioside has an important role in the maintenance of the cell membrane integrity, regulation of brain development, neuroplasticity and memory formation (Palmano et al. 2015). Following an HI event, a reduction in monosialoganglioside concentrations occurs (Ramirez et al. 2003). Monosialoganglioside therapy offers protection against apoptotic injury (Ferrari et al. 1995), prevention of neurotoxicity and reduction of brain injury (Ballough et al. 1998). Li et al. (2019) evaluated 12 experimental studies with and showed improve prognosis for neonates with HIE treated with monosialoganglioside and promote recovery ( $\mathrm{Li}$ et al. 2019). Sheng and Li (2017) evaluated 10 clinical trials of neonates administered monosialoganglioside. Reduction of the risk for a major neurodevelopment disorder, such as cerebral palsy and mental retardation, was observed. However, optimal dose, safety and long-term outcome of the treatment with monosialogangliosides has not been investigated to date (Sheng and Li 2017).

\section{Neurogenesis agents}

Stem cells

Stem cells are able to differentiate into multiple cell types from the same germ layer (multipotency), undergo self-renewal and make identical daughter cells by cell division (Weiss et al. 1996). Several sources for neuronal stem cells (NSCs) were used in neonatal HIE studies: mesenchymal stem cells (MSCs), induced pluripotent stem cells (iPSCs), embryonic stem cells (ESCs), umbilical cord stem cells and umbilical cord blood cells. NSCs are found in adult and neonate human brain mainly in the hippocampus and subventricular zone and can differentiate into functional cellular subtypes, such as neurons, astrocytes and oligodendrocytes (Weiss et al. 1996, Titomanlio et al. 2011). ESCs are derived from blastocyst and are a good source of stem cells; however, ESCs form teratomas after transplantation in vivo (Björklund et al. 2002). It is possible to purify the tumour cells; however, the remaining cells will not form NSCs (Chung et al. 2006). iPSCs are somatic cells that are terminally differentiated and exhibit nuclear reprogramming ( $\mathrm{Yu}$ et al. 2007). This method can produce autograft stem cell with no graft-vs-host reaction (Titomanlio et al. 2011). MSCs are found in bone marrow, placenta, and umbilical cord stroma and are able to differentiate into mesodermal tissues, such as bone, cartilage and fat (Pappa and Anagnou 2009). MSCs with the absence of major histocompatibility complex II (MHCII) molecules exhibit low immunogenicity and have immunosuppressive and anti-inflammatory features. In addition, these cells stimulate neurogenesis, angiogenesis, synaptogenesis and proliferation of astrocytes; increase remyelination; and exhibit antiapoptotic function. All these features of MSCs suggest that MSCs represent a potential treatment for HIE (Kaplan et al. 2011, Castillo-Melendez et al. 2013). NSCs must be administered directly into the brain tissue, whereas MSCs can be administered intravenously (Titomanlio et al. 2011). An intranasal application is a new method for the administration of stem cells; therefore, MSCs can cross the cribriform plate and migrate into the brain (Danielyan et al. 2009). Stem cells should be administered between 4 to $48 \mathrm{~h}$ following $\mathrm{HI}$ insult. However, late administration (10 days) also showed a significant positive effect on neonate animals (Van Velthoven et al. 2010). Stem cell dosing is important due to a possible toxic reaction that can develop as a result of an inflammatory response or neoplastic development. Experimental studies have shown a decrease in neuronal tissue cell death and behavioural improvement, such as better cognitive performance following stem cell treatment applied following an HI event (Van Velthoven et al. 2010, Dixon et al. 2015, Pacella et al. 2017). Although stem cell therapy demonstrate good result in animal models, the studies still need investigate the right cell for treatment, the effect on newborn compared to adult, the method of administration, the right timing, the optimal dose, and the safety of this treatment (Chang et al. 2017). Currently there are nine clinical trial which study mainly the safety of this therapy (Nitkin et al. 2020). 


\section{Conclusions}

Achieving an effective treatment for HIE is one of the great challenges facing modern medicine. Substantial efforts have been made to analyze the mechanisms leading to brain cell damage after perinatal asphyxia with the aim of developing an effective treatment; however, there are still some gaps in our knowledge concerning the pathophysiology of neurodegenerative mechanisms. Therapeutic hypothermia with NICU supportive treatment is the only approved treatment for infants with HIE. It is a leading example of how physiological understanding combined with animal models leads to the development of effective treatment approaches. Recent studies suggest that current treatment protocols are only partially effective as many infants still suffer from severe brain damage and exhibit neurological impairments. Thus, further research to systematically test promising neuroprotective treatments in combination with hypothermia is essential. In this review, we described different promising modalities in the preclinical and clinical studies. Despite the advances made in clinical studies with the use of EPO, melatonin, allopurinol, noble gasses, $\mathrm{MgSO}_{4}$, TOP, Monosialoganglioside and stem cells for neonatal HIE, more studies must be done with larger group samples and determine the safety, optimal dose, timing and method of administration of each treatment. The preclinical studies are focus on three main treatment approaches; antioxidant agents (e.g. NAC, DF, edaravone, resveratrol, DHA, ADNF-9 and NAP.), antiinflammatory agents (OPN, IFN- $\beta$, SB, azithromycin, MPSS.) and anti-excitotoxic agent (cannabinoids agonist). Besides, preclinical studies are still needed to be done and elucidate the mechanisms of action of some of these molecules, to determine the optimal dose, timing and method of administration.

\section{Conflict of Interest}

There is no conflict of interest.

\section{Acknowledgements}

The study was supported by the Charles University (Project GA UK No 454218) and the research programs PROGRES Q35 and Q25.

\section{References}

ALLEN KA, BRANDON DH: Hypoxic ischemic encephalopathy: pathophysiology and experimental treatments. Newborn Infant Nurs Rev 11: 125-133, 2011. https://doi.org/10.1053/i.nainr.2011.07.004

ALSINA M, MARTÍN-ANCEL A, ALARCON-ALLEN A, ARCA G, GAYÁ F, GARCÍA-ALIX A: The severity of hypoxic-ischemic encephalopathy correlates with multiple organ dysfunction in the hypothermia era. Pediatr Crit Care Med 18: 234-240, 2017. https://doi.org/10.1097/PCC.0000000000001068

ALTAMENTOVA S, RUMAJOGEE P, HONG J, BELDICK SR, PARK SJ, YEE A, FEHLINGS MG: Methylprednisolone reduces persistent post-ischemic inflammation in a rat hypoxia-ischemia model of perinatal stroke. Transl Stroke Res: 1117-1136, 2020. https://doi.org/10.1007/s12975-020-00792-2

ALVAREZ FJ, LAFUENTE H, REY-SANTANO MC, MIELGO VE, GASTIASORO E, RUEDA M, PERTWEE RG, CASTILLO AI, ROMERO J, MARTINEZ-ORGADO J: Neuroprotective effects of the nonpsychoactive cannabinoid cannabidiol in hypoxic-ischemic newborn piglets. Pediatr Res 64: 653-658, 2008. https://doi.org/10.1203/PDR.0b013e318186e5dd

ALY H, ELMAHDY H, EL-DIB M, ROWISHA M, AWNY M, EL-GOHARY T, ELBATCH M, HAMISA M, EL-MASHAD A: Melatonin use for neuroprotection in perinatal asphyxia: a randomized controlled pilot study. J Perinatol 35: 186-191, 2015. https://doi.org/10.1038/jp.2014.186

AMANTEA D, CERTO M, PETRELLI F, TASSORELli C, MICIELI G, CORASANITI MT, PUCCETTI P, FALLARINO F, BAGETTA G: Azithromycin protects mice against ischemic stroke injury by promoting macrophage transition towards M2 phenotype. Exp Neurol 275: 116-125, 2016. https://doi.org/10.1016/j.expneurol.2015.10.012

AMER AR, OORSCHOT DE: Xenon combined with hypothermia in perinatal hypoxic-ischemic encephalopathy: a noble gas, a noble mission. Pediatr Neurol 84: 5-10, 2018. https://doi.org/10.1016/j.pediatrneurol.2018.02.009

ANNA R, ROLF R, MARK C: Update of the organoprotective properties of xenon and argon: from bench to beside. Intensive Care Med Exp 8: 11, 2020. https://doi.org/10.1186/s40635-020-0294-6 
ARTEAGA O, ÁLVAREZ A, REVUELTA M, SANTAOLALLA F, URTASUN A, HILARIO E: Role of antioxidants in neonatal hypoxic-ischemic brain injury: new therapeutic approaches. Int J Mol Sci 18: 265, 2017. https://doi.org/10.3390/ijms18020265

ARTEAGa O, REVUELTA M, URIGÜEN L, ALVAREZ A, MONTAlVO H, HilARIO E: Pretreatment with resveratrol prevents neuronal injury and cognitive deficits induced by perinatal hypoxia-ischemia in rats. PLoS One 10: e0142424, 2015. https://doi.org/10.1371/journal.pone.0142424

AZZOPARDI D, ROBERTSON NJ, BAINBRIDGE A, CADY E, CHARLES-EDWARDS G, DEIERL A, FAGIOLO G, FRANKS NP, GRIFFITHS J, HAJNAL J: Moderate hypothermia within $6 \mathrm{~h}$ of birth plus inhaled xenon versus moderate hypothermia alone after birth asphyxia (TOBY-Xe): a proof-of-concept, open-label, randomised controlled trial. Lancet Neurol 15: 145-153, 2016. https://doi.org/10.1016/S1474-4422(15)00347-6

BALLOUGH GP, CANN FJ, SMITH CD, FORSTER JS, KLING CE, FILBERT MG: GM1 monosialoganglioside pretreatment protects against soman-induced seizure-related brain damage. Mol Chem Neuropathol 34: 1-23, 1998. https://doi.org/10.1007/BF02815133

BARKS JD, LIU Y, WANG L, PAI MP, SILVERSTEIN FS: Repurposing azithromycin for neonatal neuroprotection. Pediatr Res 86: 444-451, 2019. https://doi.org/10.1038/s41390-019-0408-6

BASSAN M, ZAMOSTIANO R, DAVIDSON A, PINHASOV A, GILADI E, PERL O, BASSAN H, BLAT C, GIBNEY G, GLAZNER G: Complete sequence of a novel protein containing a femtomolar-activity-dependent neuroprotective peptide. J Neurochem 72: 1283-1293, 1999. https://doi.org/10.1046/j.1471-4159.1999.0721283.x

BASTIANETTO S, MÉNARD C, QUIRION R: Neuroprotective action of resveratrol. Biochim Biophys Acta 1852: 1195-1201, 2015. https://doi.org/10.1016/j.bbadis.2014.09.011

BAYDAS G, REITER RJ, AKBULUT M, TUZCU M, TAMER S: Melatonin inhibits neural apoptosis induced by homocysteine in hippocampus of rats via inhibition of cytochrome $\mathrm{c}$ translocation and caspase- 3 activation and by regulating pro- and anti-apoptotic protein levels. Neuroscience 135: 879-886, 2005. https://doi.org/10.1016/j.neuroscience.2005.05.048

BENDERS MJ, BOS AF, RADEMAKER CM, RIJKEN M, TORRANCE HL, GROENENDAAL F, VAN BEL F: Early postnatal allopurinol does not improve short term outcome after severe birth asphyxia. Arch Dis Child Fetal Neonatal Ed 91: F163-F165, 2006. https://doi.org/10.1136/adc.2005.086652

BERMAN DR, MOZURKEWICH E, LIU Y, SHANGGUAN Y, BARKS JD, SILVERSTEIN FS: Docosahexaenoic acid augments hypothermic neuroprotection in a neonatal rat asphyxia model. Neonatology 104: 71-78, 2013. https://doi.org/10.1159/000351011

BERNAUDIN M, MARTI HH, ROUSSEL S, DIVOUX D, NOUVELOT A, MACKENZIE ET, PETIT E: A potential role for erythropoietin in focal permanent cerebral ischemia in mice. J Cereb Blood Flow Metab 19: 643-651, 1999. https://doi.org/10.1097/00004647-199906000-00007

BJÖRKLUND LM, SÁNCHEZ-PERNAUTE R, CHUNG S, ANDERSSON T, CHEN IYC, MCNAUGHT KSP, BROWNELL A-L, JENKINS BG, WAHLESTEDT C, KIM K-S, ISACSON O: Embryonic stem cells develop into functional dopaminergic neurons after transplantation in a Parkinson rat model. Proc Natl Acad Sci U S A 99: 2344-2349, 2002. https://doi.org/10.1073/pnas.022438099

BONESTROO HJ, NIJBOER CH, VAN VELTHOVEN CT, VAN BEL F, HEIJNEN CJ: The neonatal brain is not protected by osteopontin peptide treatment after hypoxia-ischemia. Dev Neurosci 37: 142-152, 2015. https://doi.org/10.1159/000369093

BRINES ML, GHEZZI P, KEENAN S, AGNELLO D, DE LANEROLLE NC, CERAMI C, ITRI LM, CERAMI A: Erythropoietin crosses the blood-brain barrier to protect against experimental brain injury. Proc Natl Acad Sci U S A 97: 10526-10531, 2000. https://doi.org/10.1073/pnas.97.19.10526

BROAD KD, FIERENS I, FLEISS B, ROCHA-FERREIRA E, EZZATI M, HASSELL J, ALONSO-ALCONADA D, BAINBRIDGE A, KAWANO G, MA D: Inhaled 45-50\% argon augments hypothermic brain protection in a piglet model of perinatal asphyxia. Neurobiol Dis 87: 29-38, 2016. https://doi.org/10.1016/j.nbd.2015.12.001

BUTLER WT: The nature and significance of osteopontin. Connect Tissue Res 23: 123-136, 1989. https://doi.org/10.3109/03008208909002412 
CAMPOS-PIRES R, ARMSTRONG SP, SEBASTIANI A, LUH C, GRUSS M, RADYUSHKIN K, HIRNET T, WERNER C, ENGELHARD K, FRANKS NP, THAL SC, DICKINSON R: Xenon improves neurologic outcome and reduces secondary injury following trauma in an in vivo model of traumatic brain injury. Crit Care Med 43: 149-158, 2015. https://doi.org/10.1097/CCM.0000000000000624

CARLONI S, PERRONE S, BUONOCORE G, LONGINI M, PROIETTI F, BALDUINI W: Melatonin protects from the long-term consequences of a neonatal hypoxic-ischemic brain injury in rats. J Pineal Res 44: 157-164, 2008. https://doi.org/10.1111/j.1600-079X.2007.00503.x

CASTILLO-MELENDEZ M, YAWNO T, JENKIN G, MILLER SL: Stem cell therapy to protect and repair the developing brain: a review of mechanisms of action of cord blood and amnion epithelial derived cells. Front Neurosci 7: 194, 2013. https://doi.org/10.3389/fnins.2013.00194

CETINKAYA M, ALKAN T, OZYENER F, KAFA IM, KURT MA, KOKSAL N: Possible neuroprotective effects of magnesium sulfate and melatonin as both pre-and post-treatment in a neonatal hypoxic-ischemic rat model. Neonatology 99: 302-310, 2011. https://doi.org/10.1159/000320643

CHANG YS, AHN SY, SUNG S, PARK WS: Stem cell therapy for neonatal disorders: prospects and challenges. Yonsei Med J 58: 266-271, 2017. https://doi.org/10.3349/ymj.2017.58.2.266

CHIU LS, ANDERTON RS, KNUCKEY NW, MELONI BP: Peptide pharmacological approaches to treating traumatic brain injury: a case for arginine-rich peptides. Mol Neurobiol 54: 7838-7857, 2017. https://doi.org/10.1007/s12035-016-0287-3

CHOI HA, BADJATIA N, MAYER SA: Hypothermia for acute brain injury-mechanisms and practical aspects. Nat Rev Neurol 8: 214, 2012. https://doi.org/10.1038/nrneurol.2012.21

CHUNG S, SHIN BS, HEDLUND E, PRUSZAK J, FERREE A, KANG UJ, ISACSON O, KIM KS: Genetic selection of sox1GFP-expressing neural precursors removes residual tumorigenic pluripotent stem cells and attenuates tumor formation after transplantation. J Neurochem 97: 1467-1480, 2006. https://doi.org/10.1111/j.1471$\underline{4159.2006 .03841 . x}$

COLELLA M, BIRAN V, BAUD O: Melatonin and the newborn brain. Early Hum Dev 102: 1-3, 2016. https://doi.org/10.1016/j.earlhumdev.2016.09.001

CONCEPCION KR, ZHANG L: Corticosteroids and perinatal hypoxic-ischemic brain injury. Drug Discov Today 23: 1718-1732, 2018. https://doi.org/10.1016/j.drudis.2018.05.019

COOPER SD, FELKINS K, BAKER TE, HALE TW: Transfer of methylprednisolone into breast milk in a mother with multiple sclerosis. J Hum Lact 31: 237-239, 2015. https://doi.org/10.1177/0890334415570970

COTTEN CM, SHANKARAN S: Hypothermia for hypoxic-ischemic encephalopathy. Expert Rev Obstet Gynecol 5: 227-239, 2010. https://doi.org/10.1586/eog.10.7

DAMMANN O, FERRIERO D, GRESSENS P: Neonatal encephalopathy or hypoxic-ischemic encephalopathy? Appropriate terminology matters. Pediatr Res 70: 1-2, 2011. https://doi.org/10.1203/PDR.0b013e318223f38d

DANEYEMEZ M, KURT E, COSAR A, YUCE E, IDE T: Methylprednisolone and vitamin E therapy in perinatal hypoxic-ischemic brain damage in rats. Neuroscience 92: 693-697, 1999. https://doi.org/10.1016/S03064522(99)00038-X

DANIELYAN L, SCHÄFER R, VON AMELN-MAYERHOFER A, BUADZE M, GEISLER J, KLOPFER T, BURKHARDT U, PROKSCH B, VERLEYSDONK S, AYTURAN M: Intranasal delivery of cells to the brain. Eur J Cell Biol 88: 315-324, 2009. https://doi.org/10.1016/j.ejcb.2009.02.001

DAVIDSON JO, WASSINK G, VAN DEN HEUIJ LG, BENNET L, GUNN AJ: Therapeutic hypothermia for neonatal hypoxic-ischemic encephalopathy-where to from here? Front Neurol 6: 2015. https://doi.org/10.3389/fneur.2015.00198

DEYKUN K, POMETLOVA M, SCHUTOVA B, MARES J: Modulations of behavioral consequences of minor cortical ischemic lesion by application of free radicals scavengers. Gen Physiol Biophys 30: 263-270, 2011. https://doi.org/10.4149/gpb_2011_03_263

DICOU E, ATTOUB S, GRESSENS P: Neuroprotective effects of leptin in vivo and in vitro. Neuroreport 12: 3947-3951, 2001. https://doi.org/10.1097/00001756-200112210-00019 
DIXON BJ, CHEN D, ZHANG Y, FLORES J, MALAGUIT J, NOWRANGI D, ZHANG JH, TANG J: Intranasal administration of interferon beta attenuates neuronal apoptosis via the JAK1/STAT3/BCL-2 pathway in a rat model of neonatal hypoxic-ischemic encephalopathy. ASN Neuro 8: 1759091416670492, 2016. https://doi.org/10.1177/1759091416670492

DIXON BJ, REIS C, HO WM, TANG J, ZHANG JH: Neuroprotective strategies after neonatal hypoxic ischemic encephalopathy. Int J Mol Sci 16: 22368-22401, 2015. https://doi.org/10.3390/ijms160922368

DOUGLAS-ESCOBAR M, WEISS MD: Hypoxic-ischemic encephalopathy: a review for the clinician. JAMA Pediatr 169: 397-403, 2015. https://doi.org/10.1001/jamapediatrics.2014.3269

DYALL SC: Long-chain omega-3 fatty acids and the brain: a review of the independent and shared effects of EPA, DPA and DHA. Front Aging Neurosci 7: 52, 2015. https://doi.org/10.3389/fnagi.2015.00052

EDWARDS AD, BROCKLEHURST P, GUNN AJ, HALLIDAY H, JUSZCZAK E, LEVENE M, STROHM B, THORESEN M, WHITELAW A, AZZOPARDI D: Neurological outcomes at 18 months of age after moderate hypothermia for perinatal hypoxic ischaemic encephalopathy: synthesis and meta-analysis of trial data. BMJ 340 : c363, 2010. https://doi.org/10.1136/bmj.c363

ERGENEKON E: Therapeutic hypothermia in neonatal intensive care unit: challenges and practical points. J Clin Neonatol 5: 8-17, 2016. https://doi.org/10.4103/2249-4847.173271

ESPOSITO E, CUZZOCREA S: Antiinflammatory activity of melatonin in central nervous system. Curr Neuropharmacol 8: 228-242, 2010. https://doi.org/10.2174/157015910792246155

FARKHONDEH T, FOLGADO SL, POURBAGHER-SHAHRI AM, ASHRAFIZADEH M, SAMARGHANDIAN S: The therapeutic effect of resveratrol: Focusing on the Nrf2 signaling pathway. Biomed Pharmacother 127: 110234, 2020. https://doi.org/10.1016/j.biopha.2020.110234

FENG EC, JIANG L: Effects of leptin on neurocognitive and motor functions in juvenile rats in a preterm brain damage model. Mol Med Rep 18: 4095-4102, 2018. https://doi.org/10.3892/mmr.2018.9389

FERNÁNDEZ-LÓPEZ D, PRADILLO JM, GARCÍA-YÉBENES I, MARTÍNEZ-ORGADO JA, MORO MA, LIZASOAIN I: The cannabinoid WIN55212-2 promotes neural repair after neonatal hypoxia-ischemia. Stroke 41: 2956-2964, 2010. https://doi.org/10.1161/STROKEAHA.110.599357

FERRARI G, ANDERSON BL, STEPHENS RM, KAPLAN DR, GREENE LA: Prevention of apoptotic neuronal death by $\mathrm{G}_{\mathrm{M} 1}$ ganglioside. J Biol Chem 270: 3074-3080, 1995. https://doi.org/10.1074/jbc.270.7.3074

FILIPPI L, FIORINI P, CATARZI S, BERTI E, PADRINI L, LANDUCCI E, DONZELLI G, BARTALENA L, FIORENTINI E, BOLDRINI A, GIAMPIETRI M, SCARAMUZZO RT, LA MARCA G, DELLA BONA ML, FIORI S, TINELLI F, BANCALE A, GUZZETTA A, CIONI G, PISANO T, FALCHI M, GUERRINI R: Safety and efficacy of topiramate in neonates with hypoxic ischemic encephalopathy treated with hypothermia (NeoNATI): a feasibility study. J Matern Fetal Neonatal Med 31: 973-980, 2018. https://doi.org/10.1080/14767058.2017.1304536

GALINSKY R, DEAN JM, LINGAM I, ROBERTSON NJ, MALLARD C, BENNET L, GUNN AJ: A systematic review of magnesium sulfate for perinatal neuroprotection: what have we learnt from the past decade? Front Neurol 11: 449, 2020. https://doi.org/10.3389/fneur.2020.00449

GAO Y, FU R, WANG J, YANG X, WEN L, FENG J: Resveratrol mitigates the oxidative stress mediated by hypoxicischemic brain injury in neonatal rats via Nrf2/HO-1 pathway. Pharm Biol 56: 440-449, 2018. https://doi.org/10.1080/13880209.2018.1502326

GARBERG HT, SOLBERG R, BARLINN J, MARTINEZ-ORGADO J, LØBERG E-M, SAUGSTAD OD: High-dose cannabidiol induced hypotension after global hypoxia-ischemia in piglets. Neonatology 112: 143-149, 2017. https://doi.org/10.1159/000471786

GARG B, SHARMA D, BANSAL A: Systematic review seeking erythropoietin role for neuroprotection in neonates with hypoxic ischemic encephalopathy: presently where do we stand. J Matern Fetal Neonatal Med 31: 3214-3224, 2018. https://doi.org/10.1080/14767058.2017.1366982

GILBERT GL, KIM HJ, WAATAJA JJ, THAYER SA: $\triangle 9$-Tetrahydrocannabinol protects hippocampal neurons from excitotoxicity. Brain Res 1128: 61-69, 2007. https://doi.org/10.1016/j.brainres.2006.03.011 
GLAZNER GW, BOLAND A, DRESSE AE, BRENNEMAN DE, GOZES I, MATTSON MP: Activity-dependent neurotrophic factor peptide (ADNF9) protects neurons against oxidative stress-induced death. J Neurochem 73 : 2341-2347, 1999. https://doi.org/10.1046/j.1471-4159.1999.0732341.x

GREGGIO S, DE PAUlA S, DE OLIVEIRA IM, TRINDADE C, ROSA RM, HENRIQUES JAP, DACOSTA JC: NAP prevents acute cerebral oxidative stress and protects against long-term brain injury and cognitive impairment in a model of neonatal hypoxia-ischemia. Neurobiol Dis 44: 152-159, 2011. https://doi.org/10.1016/j.nbd.2011.06.018

GUPTA Y, GUPTA M, KOHLI K: Neuroprotective role of melatonin in oxidative stress vulnerable brain. Indian J Physiol Pharmacol 47: 373-386, 2003.

HALL ED: Methylprednisolone for the treatment of patients with acute spinal cord injuries: A propensity scorematched cohort study from a Canadian multi-center spinal cord injury registry. J Neurotrauma 33: 972-974, 2016. https://doi.org/10.1089/neu.2016.4473

HANSON LR, ROEYTENBERG A, MARTINEZ PM, COPPES VG, SWEET DC, RAO RJ, MARTI DL, HOEKMAN JD, MATTHEWS RB, FREY WH: Intranasal deferoxamine provides increased brain exposure and significant protection in rat ischemic stroke. J Pharmacol Exp Ther 330: 679-686, 2009. https://doi.org/10.1124/jpet.108.149807

HOBBS C, THORESEN M, TUCKER A, AQUILINA K, CHAKKARAPANI E, DINGLEY J: Xenon and hypothermia combine additively, offering long-term functional and histopathologic neuroprotection after neonatal hypoxia/ischemia. Stroke 39: 1307-1313, 2008. https://doi.org/10.1161/STROKEAHA.107.499822

HOFFMAN DJ, MARRO PJ, MCGOWAN JE, MISHRA OP, DELIVORIA-PAPADOPOULOS M: Protective effect of MgSO4 infusion on NMDA receptor binding characteristics during cerebral cortical hypoxia in the newborn piglet. Brain Res 644: 144-149, 1994. https://doi.org/10.1016/0006-8993(94)90357-3

HU S, CHENG D, PENG D, TAN J, HUANG Y, CHEN C: Leptin attenuates cerebral ischemic injury in rats by modulating the mitochondrial electron transport chain via the mitochondrial STAT3 pathway. Brain Behav 9: e01200, 2019. https://doi.org/10.1002/brb3.1200

HUUN MU: Omega-3 Treatment in Hypoxicischemic Brain Injury: An Experimental Study in Newborn Piglets. 2019. $\mathrm{PhD}$ Thesis.

JACOBS SE, BERG M, HUNT R, TARNOW-MORDI WO, INDER TE, DAVIS PG: Cooling for newborns with hypoxic ischaemic encephalopathy. Cochrane Database Syst Rev 2013: CD003311, 2013. https://doi.org/10.1002/14651858.CD003311.pub3

JACOBS SE, MORLEY CJ, INDER TE, STEWART MJ, SMITH KR, MCNAMARA PJ, WRIGHT IM, KIRPALANI HM, DARLOW BA, DOYLE LW: Whole-body hypothermia for term and near-term newborns with hypoxicischemic encephalopathy: a randomized controlled trial. Arch Pediatr Adolesc Med 165: 692-700, 2011. https://doi.org/10.1001/archpediatrics.2011.43

JANOWSKA J, SYPECKA J: Therapeutic strategies for leukodystrophic disorders resulting from perinatal asphyxia: focus on myelinating oligodendrocytes. Mol Neurobiol 55: 4388-4402, 2018. https://doi.org/10.1007/s12035-017$\underline{0647-7}$

JATANA M, SINGH I, SINGH AK, JENKINS D: Combination of systemic hypothermia and N-acetylcysteine attenuates hypoxic-ischemic brain injury in neonatal rats. Pediatr Res 59: 684-689, 2006. https://doi.org/10.1203/01.pdr.0000215045.91122.44

JAWORSKA J, ZALEWSKA T, SYPECKA J, ZIEMKA-NALECZ M: Effect of the HDAC inhibitor, sodium butyrate, on neurogenesis in a rat model of neonatal hypoxia-ischemia: potential mechanism of action. Mol Neurobiol 56: 6341-6370, 2019. https://doi.org/10.1007/s12035-019-1518-1

JAWORSKA J, ZIEMKA-NALECZ M, SYPECKA J, ZALEWSKA T: The potential neuroprotective role of a histone deacetylase inhibitor, sodium butyrate, after neonatal hypoxia-ischemia. J Neuroinflammation 14: $34,2017$. https://doi.org/10.1186/s12974-017-0807-8

JAYALAKSHMI K, SAIRAM M, SINGH S, SHARMA S, ILAVAZHAGAN G, BANERJEE P: Neuroprotective effect of $\mathrm{N}$-acetyl cysteine on hypoxia-induced oxidative stress in primary hippocampal culture. Brain Res 1046: 97-104, 2005. https://doi.org/10.1016/j.brainres.2005.03.054 
JEREZ-CALERO A, SALVATIERRA-CUENCA MT, BENITEZ-FELIPONI Á, FERNÁNDEZ-MARÍN CE, NARBONA-LÓPEZ E, UBEROS-FERNÁNDEZ J, MUÑOZ-HOYOS A: Hypothermia plus melatonin in asphyctic newborns: a randomized-controlled pilot study. Pediatr Crit Care Med 21: 647-655, 2020. https://doi.org/10.1097/PCC.0000000000002346

JONES NM, KARDASHYAN L, CALLAWAY JK, LEE EM, BEART PM: Long-term functional and protective actions of preconditioning with hypoxia, cobalt chloride, and desferrioxamine against hypoxic-ischemic injury in neonatal rats. Pediatr Res 63: 620-624, 2008. https://doi.org/10.1203/PDR.0b013e31816d9117

JUUL SE, HARCUM J, LI Y, CHRISTENSEN RD: Erythropoietin is present in the cerebrospinal fluid of neonates. J Pediatr 130: 428-430, 1997. https://doi.org/10.1016/S0022-3476(97)70205-1

KAANDORP JJ, VAN BEL F, VEEN S, DERKS JB, GROENENDAAL F, RIJKEN M, ROZE E, VENEMA MMU, RADEMAKER CM, BOS AF: Long-term neuroprotective effects of allopurinol after moderate perinatal asphyxia: follow-up of two randomised controlled trials. Arch Dis Child Fetal Neonatal Ed 97: F162-F166, 2012. https://doi.org/10.1136/archdischild-2011-300356

KAPLAN JM, YOUD ME, LODIE TA: Immunomodulatory activity of mesenchymal stem cells. Curr Stem Cell Res Ther 6: 297-316, 2011. https://doi.org/10.2174/157488811797904353

KHAN M, SEKHON B, JATANA M, GIRI S, GILG AG, SEKHON C, SINGH I, SINGH AK: Administration of $\mathrm{N}$-acetylcysteine after focal cerebral ischemia protects brain and reduces inflammation in a rat model of experimental stroke. J Neurosci Res 76: 519-527, 2004. https://doi.org/10.1002/jnr.20087

KIESEIER BC: The mechanism of action of interferon- $\beta$ in relapsing multiple sclerosis. CNS Drugs 25: 491-502, 2011. https://doi.org/10.2165/11591110-000000000-00000

KLETKIEWICZ H, KLIMIUK M, WOŹNIAK A, MILA-KIERZENKOWSKA C, DOKLADNY K, ROGALSKA J: How to improve the antioxidant defense in asphyxiated newborns-lessons from animal models. Antioxidants (Basel) 9: E898, 2020. https://doi.org/10.3390/antiox9090898

KLETKIEWICZ H, NOWAKOWSKA A, SIEJKA A, MILA-KIERZENKOWSKA C, WOŹNIAK A, CAPUTA M, ROGALSKA J: Deferoxamine improves antioxidative protection in the brain of neonatal rats: the role of anoxia and body temperature. Neurosci Lett 628: 116-122, 2016. https://doi.org/10.1016/j.neulet.2016.06.022

KUMRAL A, TUZUN F, YESILIRMAK D, DUMAN N, OZKAN H: Role of epigenetic regulatory mechanisms in neonatal hypoxic-ischemic brain injury. Med Hypotheses 72: 692-693, 2009. https://doi.org/10.1016/j.mehy.2008.10.032

KUMRAL A, YESILIRMAK DC, SONMEZ U, BASKIN H, TUGYAN K, YILMAZ O, GENC S, GOKMEN N, GENC K, DUMAN N, OZKAN H: Neuroprotective effect of the peptides ADNF-9 and NAP on hypoxic-ischemic brain injury in neonatal rats. Brain Res 1115: 169-178, 2006. https://doi.org/10.1016/j.brainres.2006.07.114

KUMRAL A, YESILIRMAK DC, SOZMEN S, ERGUR BU, TUGYAN K, OZBAL S, GUCLU S, DUMAN N, OZKAN H: Effect of leptin treatment on neonatal hypoxic-ischemic brain injury. J Matern Fetal Neonatal Med 25: 141-146, 2012. https://doi.org/10.3109/14767058.2011.565834

LAFUENTE H, PAZOS MR, ALVAREZ A, MOHAMMED N, SANTOS M, ARIZTI M, ALVAREZ FJ, MARTINEZ-ORGADO JA: Effects of cannabidiol and hypothermia on short-term brain damage in new-born piglets after acute hypoxia-ischemia. Front Neurosci 10: 323, 2016. https://doi.org/10.3389/fnins.2016.00323

LAPTOOK AR, SHANKARAN S, TYSON JE, MUNOZ B, BELL EF, GOLDBERG RN, PARIKH NA, AMBALAVANAN N, PEDROZA C, PAPPAS A: Effect of therapeutic hypothermia initiated after 6 hours of age on death or disability among newborns with hypoxic-ischemic encephalopathy: a randomized clinical trial. JAMA 318: 1550-1560, 2017. https://doi.org/10.1001/jama.2017.14972

LAW LS-C, LO EA-G, CHAN CC-C, GAN TJ: Neurologic and cognitive outcomes associated with the clinical use of xenon: a systematic review and meta-analysis of randomized-controlled trials. Can J Anesth 65: 1041-1056, 2018. https://doi.org/10.1007/s12630-018-1163-6

LAWN JE, COUSENS S, ZUPAN J, TEAM LNSS: 4 million neonatal deaths: when? Where? Why? Lancet 365: 891-900, 2005. https://doi.org/10.1016/S0140-6736(05)71048-5 
LEE ACC, KOZUKI N, BLENCOWE H, VOS T, BAHALIM A, DARMSTADT GL, NIERMEYER S, ELLIS M, ROBERTSON NJ, COUSENS S, LAWN JE: Intrapartum-related neonatal encephalopathy incidence and impairment at regional and global levels for 2010 with trends from 1990. Pediatr Res 74: 50-72, 2013. https://doi.org/10.1038/pr.2013.206

LEKER RR, TEICHNER A, GRIGORIADIS N, OVADIA H, BRENNEMAN DE, FRIDKIN M, GILADI E, ROMANO J, GOZES I: NAP, a femtomolar-acting peptide, protects the brain against ischemic injury by reducing apoptotic death. Stroke 33: 1085-1092, 2002. https://doi.org/10.1161/01.STR.0000014207.05597.D7

LEVITON A, NELSON KB: Problems with definitions and classifications of newborn encephalopathy. Pediatr Neurol 8: 85-90, 1992. https://doi.org/10.1016/0887-8994(92)90026-U

LI C, MO Z, LEI J, LI H, FU R, HUANG Y, LUO S, ZHANG L: Edaravone attenuates neuronal apoptosis in hypoxicischemic brain damage rat model via suppression of TRAIL signaling pathway. Int J Biochem Cell Biol 99: 169-177, 2018. https://doi.org/10.1016/j.biocel.2018.03.020

LI W, YANG J, ZHOU D, ZHANG J, ZHUO Q: Meta-analysis evaluation of the treatment of neonatal hypoxicischemic encephalopathy with ganglioside. Biocell 43: 7, 2019. https://doi.org/10.32604/biocell.2019.04763

LI Y-X, DING S-J, XIAO L, GUO W, ZHAN Q: Desferoxamine preconditioning protects against cerebral ischemia in rats by inducing expressions of hypoxia inducible factor $1 \alpha$ and erythropoietin. Neurosci Bull 24: 89-95, 2008. https://doi.org/10.1007/s12264-008-0089-3

LINGAM I, ROBERTSON NJ: Magnesium as a neuroprotective agent: a review of its use in the fetus, term infant with neonatal encephalopathy, and the adult stroke patient. Dev Neurosci 40: 1-12, 2018. https://doi.org/10.1159/000484891

LIU Y, BARKS JD, XU G, SILVERSTEIN FS: Topiramate extends the therapeutic window for hypothermia-mediated neuroprotection after stroke in neonatal rats. Stroke 35: 1460-1465, 2004. https://doi.org/10.1161/01.STR.0000128029.50221.fa

LUCKI NC, SEWER MB: Nuclear sphingolipid metabolism. Ann Rev Physiol 74: 131-151, 2012. https://doi.org/10.1146/annurev-physiol-020911-153321

LUND SA, GIACHELLI CM, SCATENA M: The role of osteopontin in inflammatory processes. J Cell Commun Signal 3: 311-322, 2009. https://doi.org/10.1007/s12079-009-0068-0

MAIWALD CA, ANNINK KV, RÜDIGER M, BENDERS MJ, VAN BEL F, ALLEGAERT K, NAULAERS G, BASSLER D, KLEBERMAß-SCHREHOF K, VENTO M: Effect of allopurinol in addition to hypothermia treatment in neonates for hypoxic-ischemic brain injury on neurocognitive outcome (ALBINO): study protocol of a blinded randomized placebo-controlled parallel group multicenter trial for superiority (phase III). BMC Pediatr 19: 210, 2019. https://doi.org/10.1186/s12887-019-1566-8

MAREŠ J, POMETLOVÁ M, DEYKUN K, KRÝSL D, ROKYTA R: An isolated epileptic seizure elicits learning impairment which could be prevented by melatonin. Epilepsy Behav 23: 199-204, 2012. https://doi.org/10.1016/j.yebeh.2011.11.018

MARESOVA D, RILJAK V, MARES J: Melatonin modulates hypoxia-induced changes of rat brain excitability. Gen Physiol Biophys 29: 67-71, 2010. https://doi.org/10.4149/gpb_2010_01_ 71

MARKOWITZ CE: Interferon-beta: mechanism of action and dosing issues. Neurology 68 (24 Suppl 4): S8-S11, 2007. https://doi.org/10.1212/01.wnl.0000277703.74115.d2

MARTINEZ-BIARGE M, DIEZ-SEBASTIAN J, WUSTHOFF CJ, MERCURI E, COWAN FM: Antepartum and intrapartum factors preceding neonatal hypoxic-ischemic encephalopathy. Pediatrics 132: e952-e959, 2013. https://doi.org/10.1542/peds.2013-0511

MARTÍNEZ-ORGADO J, FERNÁNDEZ-FRUTOS B, GONZÁLEZ R, ROMERO E, URIGÜEN L, ROMERO J, VIVEROS MP: Neuroprotection by the cannabinoid agonist WIN-55212 in an in vivo newborn rat model of acute severe asphyxia. Brain Res Mol Brain Res 114: 132-139, 2003. https://doi.org/10.1016/S0169328X(03)00163-3

MATĚJOVSKÁ I, BERNÁŠKOVÁ K, KRÝSL D, MAREŠ J: Influence of melatonin pretreatment and preconditioning by hypobaric hypoxia on the development of cortical photothrombotic ischemic lesion. Physiol Res 57: 283-288, 2008. 
MILLAR LJ, SHI L, HOERDER-SUABEDISSEN A, MOLNÁR Z: Neonatal hypoxia ischaemia: mechanisms, models, and therapeutic challenges. Front Cell Neurosci 11: 2017. https://doi.org/10.3389/fncel.2017.00078

MOHAMMED N, CEPRIAN M, JIMENEZ L, RUTH PAZOS M, MARTÍNEZ-ORGADO J: Neuroprotective effects of cannabidiol in hypoxic ischemic insult. The therapeutic window in newborn mice. CNS Neurol Disord Drug Targets 16: 102-108, 2017. https://doi.org/10.2174/1871527315666160927110305

MURDEN S, BORBÉLYOVÁ V, LAŠTU゚VKA Z, MYSLIVEČEK J, OTÁHAL J, RILJAK V: Gender differences involved in the pathophysiology of the perinatal hypoxic-ischemic damage. Physiol Res 68 (Suppl 3): S207-S217, 2019. https://doi.org/10.33549/physiolres. 934356

NAGAYAMA T, SINOR AD, SIMON RP, CHEN J, GRAHAM SH, JIN K, GREENBERG DA: Cannabinoids and neuroprotection in global and focal cerebral ischemia and in neuronal cultures. J Neurosci 19: 2987-2995, 1999. https://doi.org/10.1523/JNEUROSCI.19-08-02987.1999

NAIR J, KUMAR VH: Current and emerging therapies in the management of hypoxic ischemic encephalopathy in neonates. Children 5: 99, 2018. https://doi.org/10.3390/children5070099

NIE X, LOWE DW, ROLLINS LG, BENTZLEY J, FRASER JL, MARTIN R, SINGH I, JENKINS D: Sex-specific effects of $\mathrm{N}$-acetylcysteine in neonatal rats treated with hypothermia after severe hypoxia-ischemia. Neurosci Res 108: 24-33, 2016. https://doi.org/10.1016/j.neures.2016.01.008

NITKIN CR, RAJASINGH J, PISANO C, BESNER GE, THÉBAUD B, SAMPATH V: Stem cell therapy for preventing neonatal diseases in the 21st century: Current understanding and challenges. Pediatr Res 87: 265-276, 2020. https://doi.org/10.1038/s41390-019-0425-5

NOH M-R, KIM SK, SUN W, PARK SK, CHOI HC, LIM JH, KIM IH, KIM H-J, KIM H, EUN B-L: Neuroprotective effect of topiramate on hypoxic ischemic brain injury in neonatal rats. Exp Neurol 201: 470-478, 2006. https://doi.org/10.1016/j.expneurol.2006.04.038

NOOR JI, IKEDA T, MISHIMA K, AOO N, OHTA S, EGASHIRA N, IWASAKI K, FUJIWARA M, IKENOUE T: Short-term administration of a new free radical scavenger, edaravone, is more effective than its long-term administration for the treatment of neonatal hypoxic-ischemic encephalopathy. Stroke 36: 2468-2474, 2005. https://doi.org/10.1161/01.STR.0000185653.49740.c6

NOOR JI, UEDA Y, IKEDA T, IKENOUE T: Edaravone inhibits lipid peroxidation in neonatal hypoxic-ischemic rats: an in vivo microdialysis study. Neurosci Lett 414: 5-9, 2007. https://doi.org/10.1016/j.neulet.2006.10.024

PACELLA MJ, DOUGLAS-ESCOBAR M, ZHENG T, WEISS MD: Stem cell therapy for brain injury in neonates. In: Frontiers in Stem Cell and Regenerative Medicine Research Vol. 3. Bentham Science Publishers, 2017, pp 68-101. https://doi.org/10.2174/9781681082578117030004

PALMANO K, ROWAN A, GUILLERMO R, GUAN J, MCJARROW P: The role of gangliosides in neurodevelopment. Nutrients 7: 3891-3913, 2015. https://doi.org/10.3390/nu7053891

PALMER C, ROBERTS RL, BERO C: Deferoxamine posttreatment reduces ischemic brain injury in neonatal rats. Stroke 25: 1039-1045, 1994. https://doi.org/10.1161/01.STR.25.5.1039

PAPPA KI, ANAGNOU NP: Novel sources of fetal stem cells: where do they fit on the developmental continuum? Regen Med 4: 423-433, 2009. https://doi.org/10.2217/rme.09.12

PAPROCKA J, KIJONKA M, RZEPKA B, SOKÓŁ M: Melatonin in hypoxic-ischemic brain injury in term and preterm babies. Int J Endocrinol 2019: 9626715, 2019. https://doi.org/10.1155/2019/9626715

PARIKH P, JUUL SE: Neuroprotective strategies in neonatal brain injury. J Pediatr 192: 22-32, 2018. https://doi.org/10.1016/j.jpeds.2017.08.031

PARNHAM MJ, HABER VE, GIAMARELLOS-BOURBOULIS EJ, PERLETTI G, VERLEDEN GM, VOS R: Azithromycin: mechanisms of action and their relevance for clinical applications. Pharmacol Ther 143: 225-245, 2014. https://doi.org/10.1016/j.pharmthera.2014.03.003

PAZOS M, CINQUINA V, GÓMEZ A, LAYUNTA R, SANTOS M, FERNÁNDEZ-RUIZ J, MARTÍNEZ-ORGADO $\mathrm{J}$ : Cannabidiol administration after hypoxia-ischemia to newborn rats reduces long-term brain injury and restores neurobehavioral function. Neuropharmacology 63: 776-783, 2012. https://doi.org/10.1016/j.neuropharm.2012.05.034 
PEETERS-SCHOLTE C, BRAUN K, KOSTER J, KOPS N, BLOMGREN K, BUONOCORE G, VAN BUUL-OFFERS S, HAGBERG H, NICOLAY K, VAN BEL F: Effects of allopurinol and deferoxamine on reperfusion injury of the brain in newborn piglets after neonatal hypoxia-ischemia. Pediatr Res 54: 516-522, 2003. https://doi.org/10.1203/01.PDR.0000081297.53793.C6

PIN TW, ELDRIDGE B, GALEA MP: A review of developmental outcomes of term infants with post-asphyxia neonatal encephalopathy. Eur J Paediatr Neurol 13: 224-234, 2009. https://doi.org/10.1016/j.ejpn.2008.05.001

PRENDERVILLE JA, KELLY ÁM, DOWNER EJ: The role of cannabinoids in adult neurogenesis. Br J Pharmacol 172: 3950-3963, 2015. https://doi.org/10.1111/bph.13186

RAMIREZ MR, MURARO F, ZYLBERSZTEJN DS, ABEL CR, ARTENI NS, LAVINSKY D, NETTO CA, TRINDADE VM: Neonatal hypoxia-ischemia reduces ganglioside, phospholipid and cholesterol contents in the rat hippocampus. Neurosci Res 46: 339-347, 2003. https://doi.org/10.1016/S0168-0102(03)00100-7

RILJAK V, KRAF J, DARYANANI A, JIRUŠKA P, OTÁHAL J: Pathophysiology of perinatal hypoxic-ischemic encephalopathy - biomarkers, animal models and treatment perspectives. Physiol Res 65 (Suppl 5): S533-S545, 2016. https://doi.org/10.33549/physiolres.933541

RILJAK V, LAŠTU゚VKA Z, MYSLIVEČEK J, BORBÉLYOVÁ V, OTÁHAL J: Early postnatal hypoxia induces behavioral deficits but not morphological damage in the hippocampus in adolescent rats. Physiol Res 69: 165-179, 2020. https://doi.org/10.33549/physiolres.934234

ROBERTSON CMT, FINER NN, GRACE MGA: School performance of survivors of neonatal encephalopathy associated with birth asphyxia at term. J Pediatr 114: 753-760, 1989. https://doi.org/10.1016/S00223476(89)80132-5

ROBERTSON NJ, FAULKNER S, FLEISS B, BAINBRIDGE A, ANDORKA C, PRICE D, POWELL E, LECKYTHOMPSON L, THEI L, CHANDRASEKARAN M: Melatonin augments hypothermic neuroprotection in a perinatal asphyxia model. Brain 136: 90-105, 2013. https://doi.org/10.1093/brain/aws285

RODRÍGUEZ-FANJUL J, FERNÁNDEZ-FEIJÓO CD, LOPEZ-ABAD M, RAMOS MGL, CABALLE RB, ALCÁNTARA-HORILLO S, CAMPRUBI MC: Neuroprotection with hypothermia and allopurinol in an animal model of hypoxic-ischemic injury: Is it a gender question? PLoS One 12: e0184643, 2017. https://doi.org/10.1371/journal.pone.0184643

SABIR H, OSREDKAR D, MAES E, WOOD T, THORESEN M: Xenon combined with therapeutic hypothermia is not neuroprotective after severe hypoxia-ischemia in neonatal rats. PLoS One 11: e0156759, 2016. https://doi.org/10.1371/journal.pone.0156759

SARNAT HB, SARNAT MS: Neonatal encephalopathy following fetal distress: a clinical and electroencephalographic study. Arch Neurol 33: 696-705, 1976. https://doi.org/10.1001/archneur.1976.00500100030012

SATOH K, IKEDA Y, SHIODA S, TOBE T, YOSHIKAWA T: Edarabone scavenges nitric oxide. Redox Rep 7: 219-222, 2002. https://doi.org/10.1179/135100002125000587

SCHIAVON AP, SOARES LM, BONATO JM, MILANI H, GUIMARAES FS, DE OLIVEIRA RMW: Protective effects of cannabidiol against hippocampal cell death and cognitive impairment induced by bilateral common carotid artery occlusion in mice. Neurotox Res 26: 307-316, 2014. https://doi.org/10.1007/s12640-014-9457-0

SCHUBERT S, BRANDL U, BRODHUN M, ULRICH C, SPALTMANN J, FIEDLER N, BAUER R: Neuroprotective effects of topiramate after hypoxia-ischemia in newborn piglets. Brain Res 1058: 129-136, 2005. https://doi.org/10.1016/j.brainres.2005.07.061

SCHUBRING C, KIESS W, ENGLARO P, RASCHER W, DOTSCH J, HANITSCH S, ATTANASIO A, BLUM W: Levels of leptin in maternal serum, amniotic fluid, and arterial and venous cord blood: relation to neonatal and placental weight. J Clin Endocrinol Metab 82: 1480-1483, 1997. https://doi.org/10.1210/jcem.82.5.3935

SHAH PS: Hypothermia: a systematic review and meta-analysis of clinical trials. Semin Fetal Neonatal Med 15: 238-246, 2010. https://doi.org/10.1016/j.siny.2010.02.003

SHANKARAN S, LAPTOOK AR, EHRENKRANZ RA, TYSON JE, MCDONALD SA, DONOVAN EF, FANAROFF AA, POOLE WK, WRIGHT LL, HIGGINS RD: Whole-body hypothermia for neonates with hypoxic-ischemic encephalopathy. N Engl J Med 353: 1574-1584, 2005. https://doi.org/10.1056/NEJMcps050929 
SHENG L, LI Z: Adjuvant treatment with monosialoganglioside may improve neurological outcomes in neonatal hypoxic-ischemic encephalopathy: A meta-analysis of randomized controlled trials. PLoS One 12: 2017. https://doi.org/10.1371/journal.pone.0183490

SHIBUTA S, VARATHAN S, KAMIBAYASHI T, MASHIMO T: Small temperature variations alter edaravoneinduced neuroprotection of cortical cultures exposed to prolonged hypoxic episodes. Br J Anaesth 104: 52-58, 2010. https://doi.org/10.1093/bja/aep320

SMITH-SWINTOSKY VL, GOZES I, BRENNEMAN DE, D'ANDREA MR, PLATA-SALAMAN CR: Activitydependent neurotrophic factor-9 and NAP promote neurite outgrowth in rat hippocampal and cortical cultures. J Mol Neurosci 25: 225-238, 2005. https://doi.org/10.1385/JMN:25:3:225

SO H-Y: Therapeutic hypothermia. Korean J Anesthesiol 59: 299-304, 2010. https://doi.org/10.4097/kjae.2010.59.5.299

SOKOLOWSKA P, PASSEMARD S, MOK A, SCHWENDIMANN L, GOZES I, GRESSENS P: Neuroprotective effects of NAP against excitotoxic brain damage in the newborn mice: implications for cerebral palsy. Neuroscience 173: 156-168, 2011. https://doi.org/10.1016/j.neuroscience.2010.10.074

SUGANUMA H, ARAI Y, KITAMURA Y, HAYASHI M, OKUMURA A, SHIMIZU T: Maternal docosahexaenoic acid-enriched diet prevents neonatal brain injury. Neuropathology 30: 597-605, 2010. https://doi.org/10.1111/j.1440-1789.2010.01114.x

SUGAWA M, SAKURAI Y, ISHIKAWA-IEDA Y, SUZUKI H, ASOU H: Effects of erythropoietin on glial cell development; oligodendrocyte maturation and astrocyte proliferation. Neurosci Res 44: 391-403, 2002. https://doi.org/10.1016/S0168-0102(02)00161-X

SUGIMOTO J, ROMANI AM, VALENTIN-TORRES AM, LUCIANO AA, KITCHEN CMR, FUNDERBURG N, MESIANO S, BERNSTEIN HB: Magnesium decreases inflammatory cytokine production: a novel innate immunomodulatory mechanism. J Immunol 188: 6338-6346, 2012. https://doi.org/10.4049/jimmunol.1101765

SUN J, WANG F, LI H, ZHANG H, JIN J, CHEN W, PANG M, YU J, HE Y, LIU J: Neuroprotective effect of sodium butyrate against cerebral ischemia/reperfusion injury in mice. Biomed Res Int 2015: 412946, 2015. https://doi.org/10.1155/2015/395895

TAGIN MA, WOOLCOTT CG, VINCER MJ, WHYTE RK, STINSON DA: Hypothermia for neonatal hypoxic ischemic encephalopathy: an updated systematic review and meta-analysis. Arch Pediatr Adolesc Med 166: 558-566, 2012. https://doi.org/10.1001/archpediatrics.2011.1772

TAKIZAWA Y, MIYAZAWA T, NONOYAMA S, GOTO Y-I, ITOH M: Edaravone inhibits DNA peroxidation and neuronal cell death in neonatal hypoxic-ischemic encephalopathy model rat. Pediatr Res 65: 636-641, 2009. https://doi.org/10.1203/PDR.0b013e3181a16a9f

TANAKA M: Pharmacological and clinical profile of the free radical scavenger edaravone as a neuroprotective agent. (Article in Japanese) Nihon Yakurigaku Zasshi 119: 301-308, 2002. https://doi.org/10.1254/fpj.119.301

TITOMANLIO L, KAVELAARS A, DALOUS J, MANI S, EL GHOUZZI V, HEIJNEN C, BAUD O, GRESSENS P: Stem cell therapy for neonatal brain injury: perspectives and challenges. Ann Neurol 70: 698-712, 2011. https://doi.org/10.1002/ana.22518

TOADER A-M, FILIP A, DECEA N, MURESAN A: Neuroprotective strategy in an experimental newborn rat model of brain ischemia and hypoxia: effects of resveratrol and hypothermia. Clujul Med 86: 203-207, 2013.

TOLAYMAT Y, DORÉ S, GRIFFIN HW, SHIH S, EDWARDS ME, WEISS MD: Inhaled gases for neuroprotection of neonates: a review. Front Pediatr 7: 558, 2020. https://doi.org/10.3389/fped.2019.00558

TREVISANI VFM, CASTRO AA, NETO JFN, ATALLAH ÁN: Cyclophosphamide versus methylprednisolone for treating neuropsychiatric involvement in systemic lupus erythematosus. Cochrane Database Syst Rev 2013: CD002265, 2013. https://doi.org/10.1002/14651858.CD002265.pub3

VAN BEL F, GROENENDAAL F: Birth asphyxia-induced brain damage: the long road to optimal reduction and prevention! Pediat Med 3: 2020. https://doi.org/10.21037/pm.2019.11.02

VAN DER KOOIJ MA, GROENENDAAL F, KAVELAARS A, HEIJNEN CJ, VAN BEL F: Neuroprotective properties and mechanisms of erythropoietin in in vitro and in vivo experimental models for hypoxia/ischemia. Brain Res Rev 59: 22-33, 2008. https://doi.org/10.1016/j.brainresrev.2008.04.007 
VAN VELTHOVEN CTJ, HEIJNEN CJ, VAN BEL F, KAVELAARS A: Osteopontin enhances endogenous repair after neonatal hypoxic-ischemic brain injury. Stroke 42: 2294-2301, 2011. https://doi.org/10.1161/STROKEAHA.110.608315

VAN VELTHOVEN CT, KAVELAARS A, VAN BEL F, HEIJNEN CJ: Repeated mesenchymal stem cell treatment after neonatal hypoxia-ischemia has distinct effects on formation and maturation of new neurons and oligodendrocytes leading to restoration of damage, corticospinal motor tract activity, and sensorimotor function. J Neurosci 30: 9603-9611, 2010. https://doi.org/10.1523/JNEUROSCI.1835-10.2010

VELDHUIS WB, DERKSEN JW, FLORIS S, VAN DER MEIDE PH, DE VRIES HE, SCHEPERS J, VOS IM, DIJKSTRA CD, KAPPELLE LJ, NICOLAY K: Interferon-beta blocks infiltration of inflammatory cells and reduces infarct volume after ischemic stroke in the rat. J Cereb Blood Flow Metab 23: 1029-1039, 2003. https://doi.org/10.1097/01.WCB.0000080703.47016.B6

VILLAPOL S, FAU S, RENOLLEAU S, BIRAN V, CHARRIAUT-MARLANGUE C, BAUD O: Melatonin promotes myelination by decreasing white matter inflammation after neonatal stroke. Pediatr Res 69: 51-55, 2011. https://doi.org/10.1203/PDR.0b013e3181fcb40b

VOLPE JJ: Perinatal brain injury: from pathogenesis to neuroprotection. Ment Retard Dev Disabil Res Rev 7: 56-64, 2001. https://doi.org/10.1002/1098-2779(200102)7:1<56::AID-MRDD1008>3.0.CO;2-A

VOLPE JJ: Neonatal encephalopathy: An inadequate term for hypoxic-ischemic encephalopathy. Ann Neurol 72: 156-166, 2012. https://doi.org/10.1002/ana.23647

WACHTEL EV, HENDRICKS-MUNOZ KD: Current management of the infant who presents with neonatal encephalopathy. Curr Probl Pediatr Adolesc Health Care 41: 132-153, 2011. https://doi.org/10.1016/i.cppeds.2010.12.002

WANG Q, LV H, LU L, REN P, LI L: Neonatal hypoxic-ischemic encephalopathy: emerging therapeutic strategies based on pathophysiologic phases of the injury. J Matern Fetal Neonatal Med 32: 3685-3692, 2019. https://doi.org/10.1080/14767058.2018.1468881

WASSINK G, DAVIDSON JO, DHILLON SK, ZHOU K, BENNET L, THORESEN M, GUNN AJ: Therapeutic hypothermia in neonatal hypoxic-ischemic encephalopathy. Curr Neurol Neurosci Rep 19: 2, 2019. https://doi.org/10.1007/s11910-019-0916-0

WEISS S, REYNOLDS BA, VESCOVI AL, MORSHEAD C, CRAIG CG, VAN DER KOOY D: Is there a neural stem cell in the mammalian forebrain? Trends Neurosci 19: 387-393, 1996. https://doi.org/10.1016/S01662236(96)10035-7

WEST T, ATZEVA M, HOLTZMAN DM: Pomegranate polyphenols and resveratrol protect the neonatal brain against hypoxic-ischemic injury. Dev Neurosci 29: 363-372, 2007. https://doi.org/10.1159/000105477

WOOD T, OSREDKAR D, PUCHADES M, MAES E, FALCK M, FLATEBØ T, WALLØE L, SABIR H, THORESEN M: Treatment temperature and insult severity influence the neuroprotective effects of therapeutic hypothermia. Sci Rep 6: 23430, 2016. https://doi.org/10.1038/srep23430

WU YW, BAUER LA, BALLARD RA, FERRIERO DM, GLIDDEN DV, MAYOCK DE, CHANG T, DURAND DJ, SONG D, BONIFACIO SL: Erythropoietin for neuroprotection in neonatal encephalopathy: safety and pharmacokinetics. Pediatrics 130: 683-691, 2012. https://doi.org/10.1542/peds.2012-0498

WU YW, GONZALEZ FF: Erythropoietin: a novel therapy for hypoxic-ischaemic encephalopathy? Dev Med Child Neurol 57 (Suppl 3): 34-39, 2015. https://doi.org/10.1111/dmcn.12730

YAMAMOTO Y, KUWAHARA T, WATANABE K, WATANABE K: Antioxidant activity of 3-methyl-1-phenyl-2pyrazolin-5-one. Redox Rep 2: 333-338, 1996. https://doi.org/10.1080/13510002.1996.11747069

YAMATO S, NAKAMURA S, HTUN Y, NAKAMURA M, JINNAI W, NAKAO Y, MITSUIE T, KOYANO K, WAKABAYASHI T, MORIMOTO AH: Intravenous edaravone plus therapeutic hypothermia offers limited neuroprotection in the hypoxic-ischaemic newborn piglet. Neonatology 2020: 1-8, 2020. https://doi.org/10.1101/2020.02.25.964288

YASUOKA N, NAKAJIMA W, ISHIDA A, TAKADA G: Neuroprotection of edaravone on hypoxic-ischemic brain injury in neonatal rats. Brain Res Dev Brain Res 151: 129-139, 2004. https://doi.org/10.1016/j.devbrainres.2004.04.006 
YOUSUF S, ATIF F, AHMAD M, HODA N, ISHRAT T, KHAN B, ISLAM F: Resveratrol exerts its neuroprotective effect by modulating mitochondrial dysfunctions and associated cell death during cerebral ischemia. Brain Res 1250: 242-253, 2009. https://doi.org/10.1016/j.brainres.2008.10.068

YU J, VODYANIK MA, SMUGA-OTTO K, ANTOSIEWICZ-BOURGET J, FRANE JL, TIAN S, NIE J, JONSDOTTIR GA, RUOTTI V, STEWART R: Induced pluripotent stem cell lines derived from human somatic cells. Science 318: 1917-1920, 2007. https://doi.org/10.1126/science.1151526

ZHANG F, WANG S, SIGNORE AP, CHEN J: Neuroprotective effects of leptin against ischemic injury induced by oxygen-glucose deprivation and transient cerebral ischemia. Stroke 38: 2329-2336, 2007. https://doi.org/10.1161/STROKEAHA.107.482786

ZHANG W, HU X, YANG W, GAO Y, CHEN J: Omega-3 polyunsaturated fatty acid supplementation confers longterm neuroprotection against neonatal hypoxic-ischemic brain injury through anti-inflammatory actions. Stroke 41: 2341-2347, 2010. https://doi.org/10.1161/STROKEAHA.110.586081

ZHOU Y, YAO Y, SHENG L, ZHANG J, ZHANG JH, SHAO A: Osteopontin as a candidate of therapeutic application for the acute brain injury. J Cell Mol Med 24: 8918-8929, 2020. https://doi.org/10.1111/jcmm.15641

ZIEMKA-NALECZ M, JAWORSKA J, SYPECKA J, POLOWY R, FILIPKOWSKI RK, ZALEWSKA T: Sodium butyrate, a histone deacetylase inhibitor, exhibits neuroprotective/neurogenic effects in a rat model of neonatal hypoxia-ischemia. Mol Neurobiol 54: 5300-5318, 2017. https://doi.org/10.1007/s12035-016-0049-2 